\title{
AMACRINE CELLS OF THE MAMMALIAN RETINA: NEUROCIRCUITRY AND FUNCTIONAL ROLES
}

\author{
HELGA KOLB \\ Salt Lake City, USA
}

\begin{abstract}
SUMMARY
Since amacrine cells are important interneurons of the inner retina and their activity may be detected in certain waveforms of the electroretinogram, this paper reviews their morphologies, classification, mosaics, neurotransmitter content, neural circuitry and physiological responses to light. Nine different amacrine cell types of cat, rabbit and human retinas are presently quite well studied in terms of the aforementioned aspects and are described in detail in this paper.
\end{abstract}

Professor Geoffrey B. Arden has devoted his research career to an understanding of the electrical activity of the retina that can be recorded from the corneal surface of the eye as the electro-oculogram (EOG), electroretinogram (ERG) and the pattern electroretinogram (PERG). Over the years, due in large part to Geoffrey Arden's research, we have come to understand that the EOG is a measure of electrical activity generated across the pigment epithelium, that the uniform field ERG is a measure of the integrity of the distal retinal neurons (photoreceptor-bipolar cell synaptic currents) while the PERG reflects the activity of the proximal retina (synaptic and dendritic currents of bipolar, amacrine and ganglion cells). ${ }^{1,2}$ Recent approaches to further dissect the retinal origins of the ERG, such as depth recordings within the retinal layers, fine tuning stimulus parameters and using computer averaging techniques of response components, have clarified that some parts of the ERG (proximal negative responses (PNR), $\mathrm{M}$ waves and oscillatory potentials) are contributed predominantly by amacrine cells. ${ }^{1}$ Thus, the role of amacrine cells in fashioning the visual message of the retina is becoming more appreciated and basic anatomical and neurocircuitry research is focusing much more intensely on under-

Correspondence to: Helga Kolb, Department of Ophthalmology, John Moran Eye Center, University of Utah School of Medicine, Salt Lake City, UT 84132, USA.

Presented at a symposium in London, 29 September 1995, in honour of Professor Geoffrey Arden. standing these retinal interneurons. It seems timely to consider here the present status of amacrine cell morphology, mosaic arrangements, circuitry and functional roles in the mammalian retina from my viewpoint as a retinal anatomist. I sincerely hope this will be of interest to clinician and basic visual scientist reader alike.

\section{MORPHOLOGICAL DIVERSITY (A FEW WORDS ON CLASSIFICATION OF AMACRINE CELLS)}

Amacrine cells of the vertebrate retina are interneurons that interact at the second synaptic level of the vertically direct pathways consisting of the photoreceptor-bipolar-ganglion cell chain. They are synaptically active in the inner plexiform layer (IPL) and serve to integrate, modulate and interpose a temporal domain to the visual message presented to the ganglion cell. Amacrine cells were so named because they are nerve cells thought to lack an axon. ${ }^{3,4}$ Today we know that certain large-field amacrine cells of the vertebrate retina can have long 'axon-like' processes that probably function as true axons in the sense that they are output fibres of the cell (see later section on dopaminergic amacrine cells). However, these amacrine axons remain within the retina and do not leave the retina in the optic nerve as do the ganglion cell axons.

Since the time of Cajal we have known that the vertebrate retina contains a great number of different nerve cell types even amongst the five general classes of cells (photoreceptors, horizontal cells, bipolar cells, amacrine cells and ganglion cells). The amacrine cells in particular can come in all shapes, sizes and stratification patterns. ${ }^{3}$ Golgi studies over the years have reaffirmed Cajal's different types of amacrine cell and have added a great many more morphological subtypes to the total. ${ }^{5-18}$ Thus, from Golgi staining studies we presently have a classification of amacrine cells consisting of 30 to 40 different morphological subtypes. 
It is useful and most easily understandable to group the nerve types into the general descriptors of narrow-field (30-150 $\mu \mathrm{m})$, small-field $(150-300 \mu \mathrm{m})$, medium-field $(300-500 \mu \mathrm{m})$ and wide-field $(>500 \mu \mathrm{m})$ based on a measurement of their dendritic field diameters. ${ }^{9,11}$ A slight danger in assigning amacrine cells to these groups is not considering variations of a cell's dendritic field size with topographical location in the retina. An amacrine cell might be called a small-field type when seen in the central retina but a medium-field type when seen in the retinal periphery. Thus one must be aware of the latter problem before proceeding to the next step in classification which involves stratification criteria.

It is generally agreed now that the IPL can be subdivided into five equi-thickness strata or sublayers ${ }^{3}$ into which amacrine, bipolar and ganglion cell processes can be assigned. All these cell types are now classified primarily on the basis of the stratum or strata of the IPL in which their dendrites or axons are located. This is because, as will become clear later, the IPL of vertebrate retinas can be divided up into areas of neuropil where specific cells are put into synaptic contacts and form circuits only with cells earmarked for a particular functional role. Many varieties of amacrine cells, as well as bipolar and ganglion cells, are monostratified, i.e. restricted to a single stratum, while others are bi- or tri-stratified. When amacrine or ganglion cell processes pass through all the strata of the IPL from distal to proximal or vice versa, they are called diffuse cells. Superimposed upon Cajal's ${ }^{3}$ five strata subdivision of the IPL, is a sublaminar division of the IPL that serves a functional purpose. The first two strata, 1-2, are known as sublamina a of the IPL, while strata 3-5 are known as sublamina $b$ by this scheme. ${ }^{19}$ Sublamina a contains bipolar axons and ganglion cell connections that lead to OFF-centre ganglion cell physiology, while sublamina b contains bipolar to ganglion cell connections resulting in ON-centre ganglion cell physiology. ${ }^{20}$

Fig. 1 shows micrographs of two important amacrine cell types of the retina that have in common that they are monostratified yet are completely different in appearance and dendritic tree shape and size. The dopaminergic amacrine cell type (Fig. 1a), labelled Toh here because such cells have been revealed by immunostaining with an antibody directed against tyrosine hydroxylase, is essentially monostratified in stratum 1 of the IPL (closest to the inner nuclear layer, INL). It is a widefield cell with processes that overlap and branch forming a densely packed network of processes that leave only few 'holes' for other amacrine cell bodies and major dendrites to pass through. In contrast, the cells labelled $\mathrm{ACh}$, taken from an intracellular Lucifer yellow staining study by Vaney, ${ }^{21}$ are examples of cholinergic 'starburst' amacrine cells of the rabbit retina (ACh-b types) (Fig. 1b). These amacrine cells have cell bodies in the ganglion cell layer, are monostratified on the stratum $3 / 4$ border of the IPL (in sublamina b), are medium-field in size and have tremendous overlap of their dendritic trees such that as many as 70 cells overlap a single central cell in peripheral retina. ${ }^{22,23} \mathrm{ACh}-\mathrm{a}$ type cells (not shown) are mirror images of the ACh-b types, differing only in their slightly larger dendritic tree sizes (13\% larger) at corresponding retinal locations, their different stratification in the IPL and placement of their cell bodies in the INL in more typical amacrine cell fashion. They stratify on the stratum $1 / 2$ border in sublamina a of the neuropil and their overlap values can reach 90 or more. ${ }^{23}$

Figs. 2, 3 and 4 show other amacrine cell types of the cat and human retinas, where some of the extremes of morphological types from smallest to widest in field size are illustrated. All these amacrine cell types have been fairly extensively studied now and we have information on their morphology, neurocircuitry and intracellular responses to light. In Fig. 2 are three examples of the best-studied amacrine of all in the vertebrate retina: the AII 'rod amacrine' of the mammalian retina. These three (Fig. $2 \mathrm{a}, \mathrm{b}$ and c) are typical cells as seen in vertical sections of cat retinas. All three have been recorded from by microelectrodes and the dyes Lucifer yellow or Procion yellow iontophoresed into the cell after the intracellular recordings. ${ }^{24}$ The AII cell, first described from Golgi staining and electron microscopic examination, ${ }^{8,25}$ is a narrow-field amacrine (dendritic tree diameter typically 30-70 $\mu \mathrm{m}$ ) with a bistratified morphology: the mitral-shaped cell body gives off a single, stout apical dendrite and a cluster of lobular appendages (Fig. 2, round blobs just below the cell body) arise from it in the distal IPL while the finer 'arboreal dendrites' 26 penetrate down into proximal IPL to end close to the ganglion cell layer. In the human retina, such an AII amacrine cell is seen in a surface view of a wholemount (Fig. 3, AII), and it has a remarkable similarity to the cat cell type, although the lobular appendages are not quite as pronounced as in cat or rabbit. ${ }^{27}$

A2, A8 and A13 types are also common narrowfield amacrine cells of the cat and human retinas. A2 has a dendritic tree composed of multibranched, beaded and appendage-bearing dendrites mostly confined to stratum 2 of the IPL (Fig. 3, A2). A8 is a bistratified, narrow-field amacrine cell that is easy to confuse with AII in wholemount, stained retina. The example from cat retina in Fig. 3 has the shorter, wispier dendritic halo coming from the cell body to ramify in strata 1 and 2 of the IPL, whereas the dendrites bearing the large beads penetrate down to the proximal IPL, strata 4 and 5. Cell A13 (Fig. 3, 

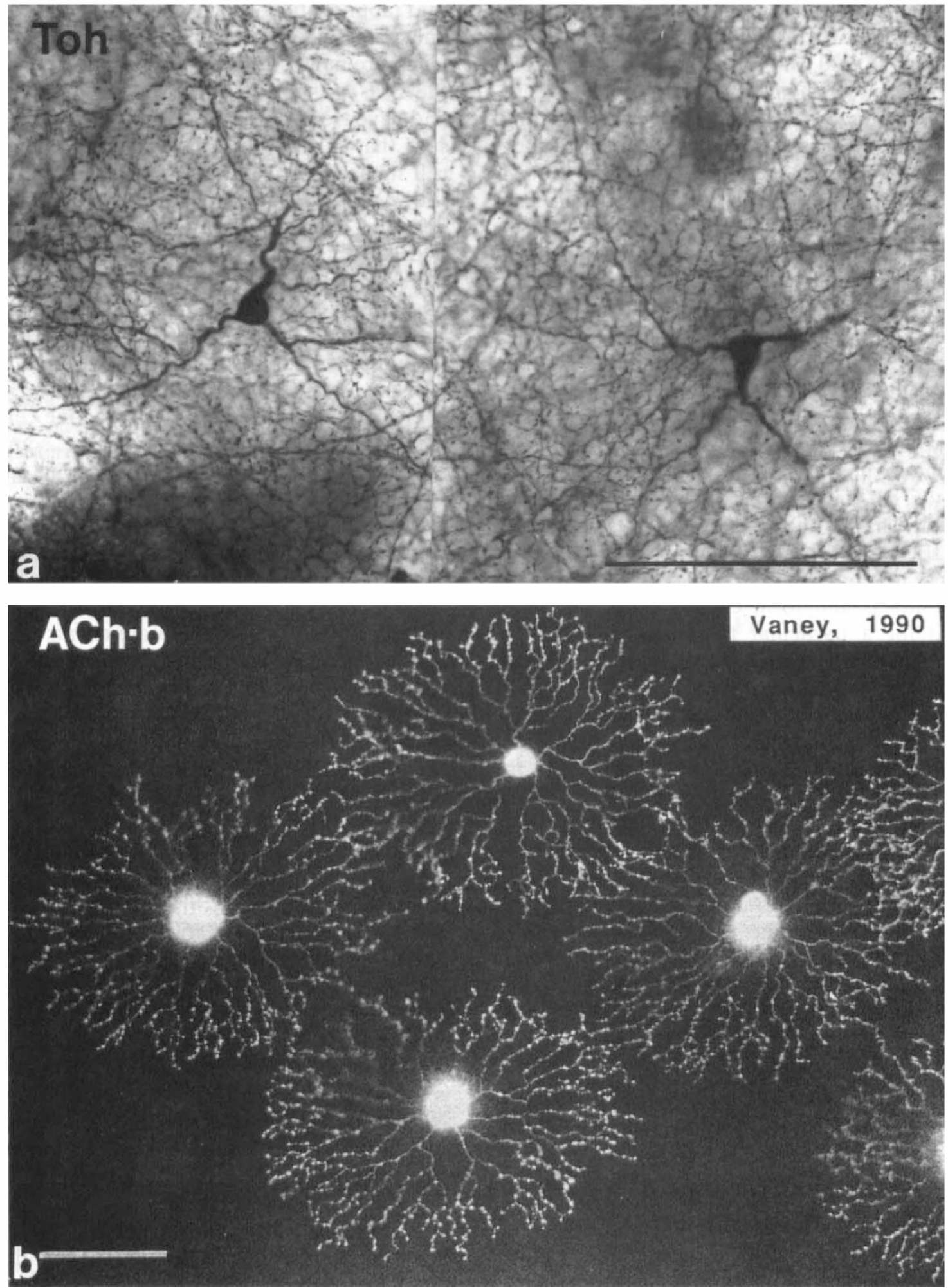

Fig. 1. (a) Light micrograph of a wholemount view of amacrine cells in the cat retina stained with antibodies to tyrosine hydroxylase (Toh). Two cells are stained, together with their dendrites and the plexus of dendrites from neighbouring Toh cells. The meshwork of dendrites is very dense, runs in stratum 1 of the IPL and leaves only few holes for amacrine cells bodies and large dendrites to penetrate. Scale bar represents $100 \mu \mathrm{m}$. (b) Displaced 'starburst' amacrine cells of the rabbit retina are seen in wholemount view after staining with intracellular injection of the fluorescent dye, Lucifer yellow. There are about 250 $A C h-b$ cell in this field (only 6 are stained by microelectrode staining). Each point in central retina like this, is overlapped by the dendritic trees of about $30 \mathrm{ACh}-b$ cells. Scale bar represents $100 \mu \mathrm{m}$. From Vaney. ${ }^{21}$ 

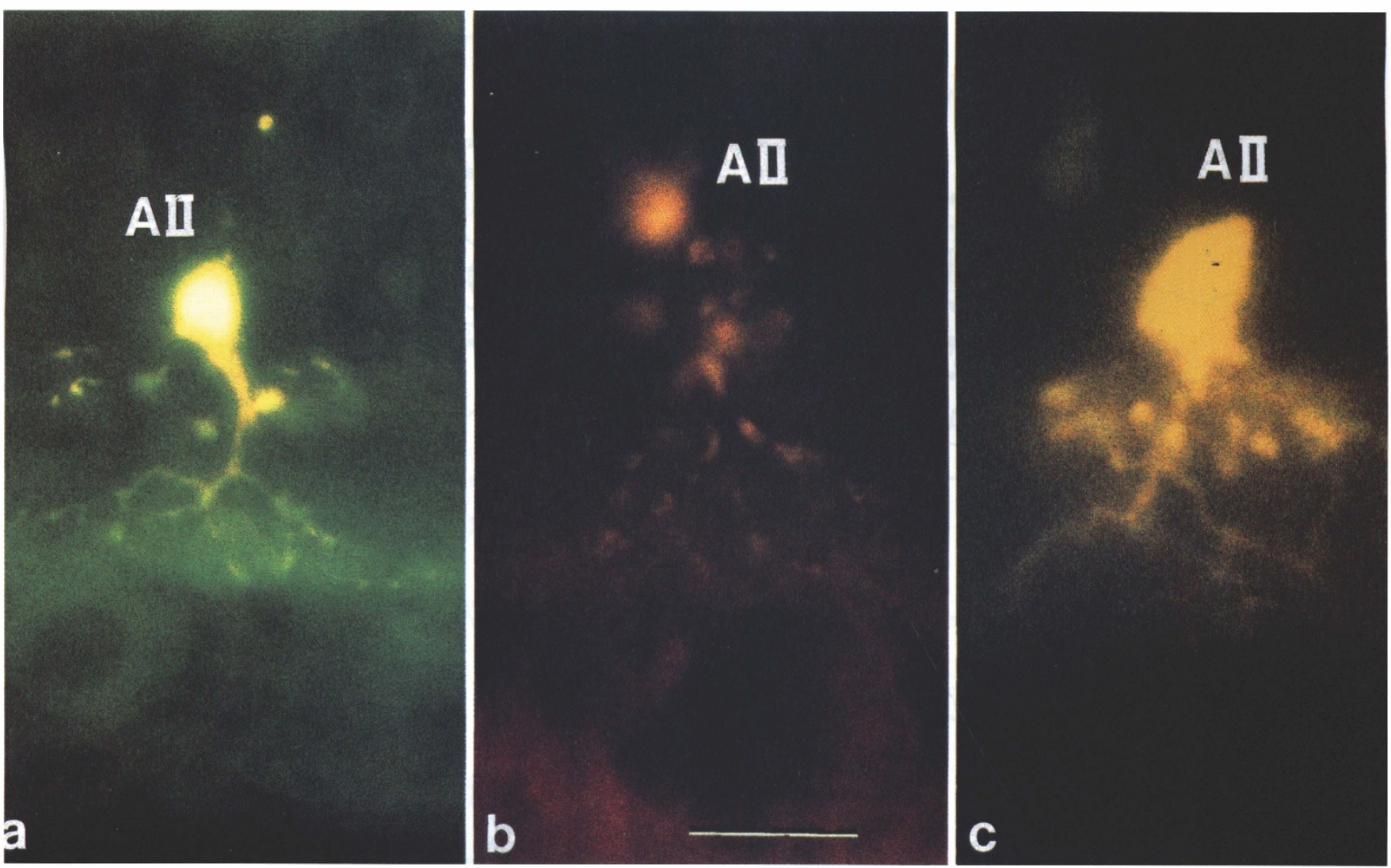

Fig. 2. Light micrographs of Lucifer yellow or Procion yellow stained AII amacrine cells after intracellular recording of light responses. The cells are viewed in vertical sections of cat retina. Scale bar represents 25 um. From Nelson. ${ }^{24}$

A13) is a diffusely branched cell with a large cell body (12 $\mu \mathrm{m}$ diameter) and fine dendrites bearing distinct beads at regular intervals that fall through all strata of the IPL to end up running along the top of ganglion cell bodies.

The wide-field cells shown in wholemount drawings in Fig. 4 are similar-looking at a superficial glance. On closer inspection, though, they are different in many regards. A18 has a widespread loose dendritic tree of very fine dendrites that are probably not fully impregnated by the Golgi stain used here. Its major dendrites run right under the amacrine cell bodies of the INL, in stratum 1 of the IPL. We consider A18 to be the dopaminergic amacrine cell of the mammalian retina. It is, of course, much more fully revealed in terms of its branching and dendritic plexus by the immunostaining technique, where the whole population of these cells with their incredible overlapping dendritic trees is dramatically displayed (see Fig. 1a). Another feature of A18, which is only seen after dye injection $^{28}$ or immunostaining, ${ }^{29}$ is the presence of long axon-like processes running in different strata of the IPL, in the ganglion cell layer and sometimes into the outer plexiform layer (OPL).

A19, A22 and A23 are all similar-appearing widefield radiate amacrine cells. All three, like A18, give off extremely long $(\mathrm{mm})$ axon-like processes either from the ends of tapering dendrites (A19, A23) or from primary dendrites or even from the cell body (A22). They differ in stratification levels, some being broadly stratified (A22, A23) others narrowly (A19). Some have spines on their dendrites (A22 and A19); others have smooth dendrites but distinct beads instead of spines (A23). A22 is commonly a displaced cell with its cell body in the ganglion cell layer. In contrast to the other four amacrine cells on the drawing (Fig. 4), A17 is a wide-field diffuse amacrine. Its dendritic tree can span close to a millimetre of retinal surface. Its very fine dendrites bear pronounced beads at regular intervals along their length and end up running along the top of the ganglion cell layer in stratum 5 of the IPL. Over 1000 beads have been counted on such A17 amacrine cells in the cat retina ${ }^{30}$ and, as we shall see later, the beads are the synaptic points where reciprocal synapses with rod bipolar cells occur.

\section{NEUROTRANSMITTERS AND MOSAIC ARRANGEMENTS OF AMACRINE CELLS IN THE MAMMALIAN RETINA}

It is now known that either $\gamma$-aminobutyric acid (GABA) or glycine account for close to $100 \%$ of the amacrine cells of the vertebrate retina. ${ }^{31,32}$ Indeed our own findings in human retina using immunocytochemical staining for these two neurotransmit- 


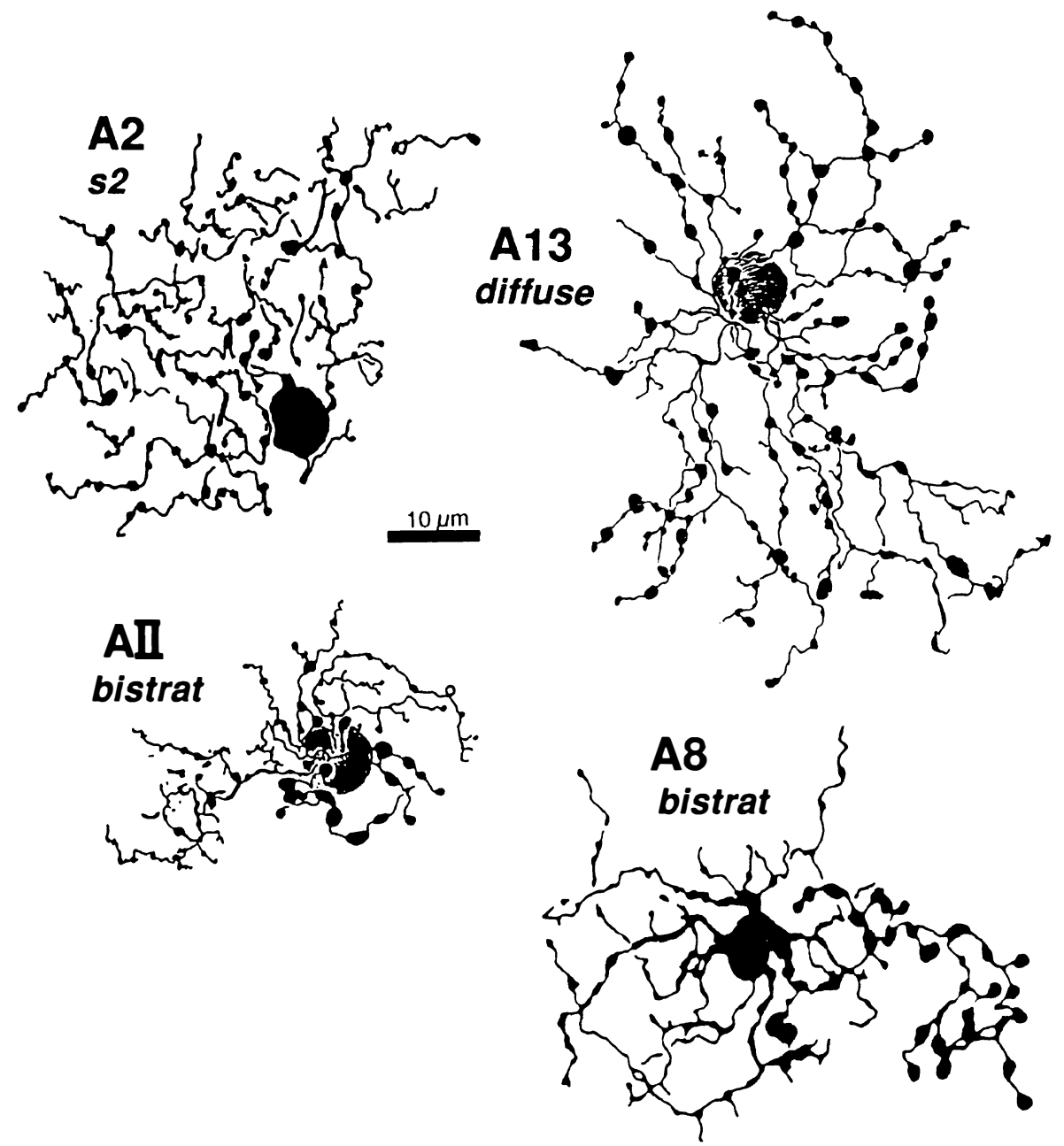

Fig. 3. Camera lucida drawings of four narrow-field amacrine cells $(<100 \mu m$ dendritic tree diameters) of the human and cat retina as seen in wholemount Golgi or HRP stains. A2 and AII are both from human retina, while A8 and A13 are from cat retina. The 's2' indicates the stratum in the IPL where the dendritic tree is located. bistrat, bistratified; diffuse, diffuse dendritic branching. Scale bar represents $10 \mu \mathrm{m}$.

ters showed that $40 \%$ of the amacrine cells appeared to localise glycine while $55 \%$ localised GABA. ${ }^{33}$ However, a great many other neurotransmitter substances, besides GABA and glycine, have been seen in mammalian amacrine cells, as summarised in Table I. But it has become apparent that these other transmitters always co-localise with either GABA or glycine even in the case of the classic excitatory transmitter acetylcholine ( $\mathrm{ACh}$ ). In fact, a considerable stir was created a few years ago when it was discovered that the starburst, $\mathrm{ACh}$-containing cells of the retina also immunostain to GABA and GAD, the synthesising enzyme for GABA. ${ }^{34-39}$

Table I lists the amacrine cell types that have now become associated with particular neurotransmitter substances in the mammalian retina. The list is compiled primarily from data of cat and rabbit retinas. However, some clearly recognisable amacrine cell types of the monkey and human retina have been included. The list is as yet incomplete concerning an exact classification of each cell type by neurotransmitter signature because of the difficulty of agreeing on correspondence between different authors' classification schemes and making crossspecies comparisons. The review article by $\mathrm{Vaney}^{21}$ is the most comprehensive treatment on the subject of the differences between cat and rabbit retina in this regard.

Immunocytochemical staining of amacrine cells, when done on wholemounts of retina, can reveal every cell of the population that is immunoreactive to the antibody used. Thus we are increasingly acquiring population maps and distribution maps of all the different types of amacrine cells according to neurotransmitter content. Most amacrine types are arranged in regular mosaics and the individual cells have certain overlap characteristics that can be calculated from nearest-neighbour statistics. The cat and monkey amacrine mosaics peak in cell density with closest packing of their smallest dendritic trees in the fovea or area centralis. Then from centre to periphery the neurons distribute evenly in concentric 


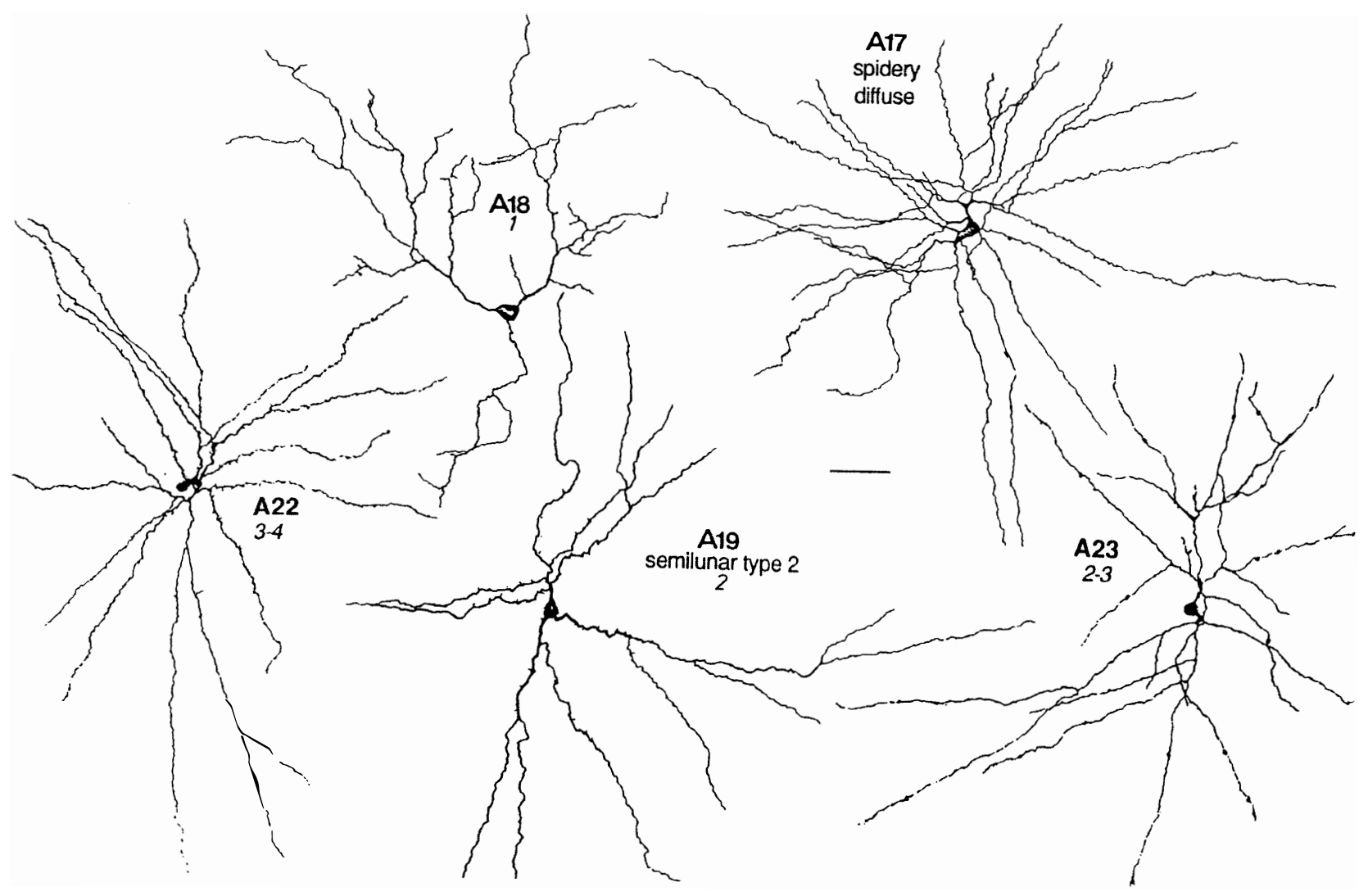

Fig. 4. Camera lucida drawings of Golgi- or HRP-stained neurons as seen in wholemounts of human and cat retina. A18, $A 19$ and $A 17$ are from human retina; $A 22$ and A23 from cat retina have been recorded and stained with $H R P .^{61}$ Scale bar represents $50 \mathrm{\mu m}$.

rings of decreasing density and increasing dendritic field sizes. The rabbit amacrine mosaics peak along the horizontally-organised visual streak and fall off therefrom linearly into superior and inferior retina. ${ }^{21}$ Some of the more sparsely distributed neurotransmitter types have unique distributions. For example, the somatostatin-immunoreactive associational neu- rons in rabbit retina are located almost exclusively in inferior retina. ${ }^{40.41}$

The commonest amacrine cell type of the cat and rabbit retina is the glycinergic AII amacrine (estimated 512000 total in cat retina) followed by the serotonin-accumulating amacrines (between 170000 and 230000 cells in rabbit retina), cholinergic cells

Table I. Common neurotransmitter substances found in mammalian amacrine cells

\begin{tabular}{llll}
\hline & & Amacrine cell type & Cat \\
\cline { 3 - 4 } Neurotransmitter & \multicolumn{1}{c}{ Rabbit } & A2, A10 & P13, A17 \\
\hline GABA & & A19, A22, A23 & \\
& & A3, A4 & AII \\
Glycine & & A8 & A8 \\
& AII & 'Starburst' & 'Starburst' \\
Acetylcholine & DAPI-3 & a-type, b-type & CA-type 1 \\
& 'Starburst' Ca, Cb & A18 & CA-type 2 \\
Dopamine & Toh-IR & A17 \\
Serotonin & CA1, CA2, CA3 & A17, A20 and A22 & Thorny 2 \\
Substance P & S1, S2 & A14, A15, A22? & \\
Vasoactive interstitial polypeptide & Tri-stratified & & \\
Somatostatin & Tri-stratified, & & \\
& same as Dopa? & Association neuron, & \\
\end{tabular}

Compiled from Vaney. ${ }^{21}$ 

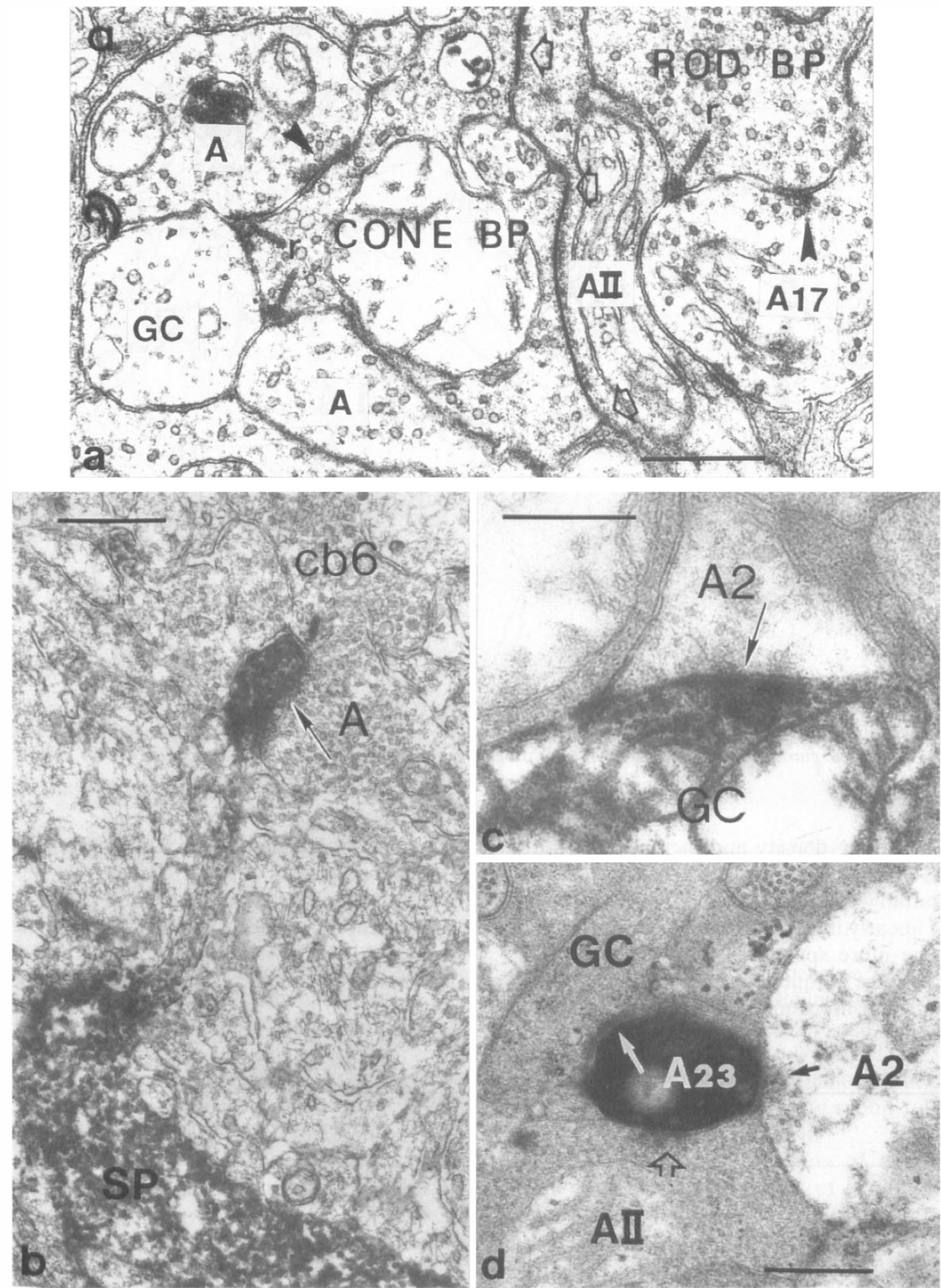

Fig. 5. (a) Electron micrograph of neural profiles in the IPL. Rod and cone bipolar axons makes synapses at ribbons ( $r)$ to a dyad of postsynaptic profiles which are AII and A17 in the case of the rod bipolar, and amacrine (A) and ganglion cell (GC) in the case of the cone bipolar. A17 is a reciprocal amacrine cell in all cases. AII makes gap junctions (large open arrows) to the cone bipolar axon. (b) Substance $P(S P)$-containing amacrine emits a spine from a major dendrite in stratum 3 of the IPL. The spine is synapsed upon by a cone bipolar cell and an unidentified amacrine cell $(A)$ (arrow). (c) $A$ pale-appearing amacrine profile, thought to be an A2 type, synapses upon an HRP-filled $\beta$ ganglion cell in the cat. (d) HRP-stained A23 is presynaptic to a ganglion cell dendrite, while at the same time it is postsynaptic to an AII lobular appendage and a putative A2 amacrine cell. Scale bars represent $0.5 \mu \mathrm{m}$. 
(approximately 130000 in rabbit retina) and substance-P-containing cell types (39000 cells in cat retina) (reviewed in $\mathrm{Vaney}^{21}$ ). Dopaminergic amacrine cells are some of the lowest density populations of cells (3000-5000 in cat; 6000-8000 in rabbit). ${ }^{21,42,43}$

\section{CIRCUITRY OF AMACRINE CELLS AS REVEALED BY ELECTRON MICROSCOPY}

Kidd $^{44}$ and later Dowling and Boycott ${ }^{45}$ were the first to identify the three types of profile that contribute to the IPL by electron microscopy. Fig. 5 a shows the cytological criteria on which we now recognise bipolar, amacrine and ganglion cell profiles in the neuropil. Thus bipolar cell axonal endings (Fig. 5a, ROD BP and CONE BP) are recognised by being filled with synaptic vesicles and having a ribbon-shaped density (synaptic bar; r) pointing to two postsynaptic profiles (Fig. 5a, A17 and AII, or A and GC). Amacrine profiles are also filled with synaptic vesicles but make synapses marked by membrane densities at which the vesicles are particularly clustered (Fig. 5a, A and A17, arrowheads; Fig. 5c and d, A2, arrows). Ganglion cell profiles are recognised as being only postsynaptic to either bipolar axons or amacrine processes, containing no vesicles but instead neurotubules, ribosomes and glycogen granules (Fig. 5a, GC).

Amacrine cell synapses are frequently seen to be reciprocal to bipolar ribbon input, i.e. the amacrine returns a synapse in the vicinity of the ribbon input synapse (Fig. 5a, A and A17, arrowheads). Most amacrine cells are inhibitory neurons in the vertebrate retina, containing the common inhibitory neurotransmitters GABA or glycine. GABAergic amacrine cells, in particular, typically make reciprocal synapses with bipolar cells. A17 is the most well studied of the GABAergic reciprocal amacrine cells in the retina. Its synaptic circuitry consists almost exclusively of reciprocal synapses with rod bipolar axon terminals in sublamina b of the IPL (Fig. 5a, A17). ${ }^{30,46-49}$

We have learnt much concerning the synaptic relationships of certain narrow-field amacrine cells as well as bipolar and small ganglion cell types such as midget ganglion cells of the primate retina, from reconstructions of serial-section electron micrographs. $8,46,50-56$ In particular, the circuitry of the AII amacrine cell in the cat retina was appreciated by this means. ${ }^{8,46}$ However, with the advent of intracellular dye injection of electron-dense materials (horseradish peroxidase (HRP) or the photoreduction of Lucifer yellow) after physiological recordings or the development of electron-dense immunostains for electron microscopy, neurocircuitry was made easier for us. ${ }^{57,58}$ We could look at amacrine cells and their synaptic inputs by study of fewer sections and it was not as critical to photograph every single section in a series. The amacrine cell of interest would always be clearly marked black, and easily found in the synaptic neuropil.

Figs. 5b-d, 6 and 7 show sample micrographs of the various amacrine cells that have been studied over the years. The cells have been stained black either by iontophoresis of HRP after intracellular recording of light responses (the ganglion cell of Fig. $5 c$, and amacrines labelled A23 and A8) or after immunostaining with antibodies directed against a neurotransmitter (SP cell, Fig. 5b) or an enzyme involved in synthesising a neurotransmitter (Toh cell in Fig. 6a-d).

Fig. $5 \mathrm{~b}$ illustrates typical features of the amacrine cell in human retina that is immunoreactive to the neuropeptide substance $P$ (SP). ${ }^{59}$ This amacrine is probably equivalent to the wide-field A22 cell of cat (Fig. 4). Its thick primary dendrites bear numerous spines that prove to be innervated by bipolar cell terminals and amacrine cells that are also postsynaptic at the same bipolar terminals (Fig. 5b, cb6, A, arrow). Narrow-field A2 amacrine cells (Fig. 3) have been reconstructed from serial-section electron microscopy and are known to make numerous synapses upon ganglion cell dendrites in stratum 2 of the IPL. ${ }^{46}$ In Fig. 5c, an unstained A2 is presynaptic (A2, arrow) upon an HRP-stained b ganglion cell in cat retina. ${ }^{60}$ A23 (Fig. 5d) is shown in its entirety in wholemount view in Fig. 3, and has been recorded and marked with HRP. It proves to be an ON-OFF responding amacrine cell type (see later section) that branches on the border of stratum $2 / 3$, making synapses upon a ganglion cell dendrite (GC) and receiving input from narrow-field, rod amacrine, AII, as well as from a putative A2 cell. ${ }^{61}$ The AII's lobular appendages of the distal IPL (strata 1 and 2, Fig. 2) are easily recognisable in the electron microscope by being large-diameter profiles, containing characteristically large mitochondria that are squashed together, and by making small punctate synapses upon postsynaptic processes of cone bipolar, ganglion cells or amacrine cells (in this case the A23 dendrite). Another recognition feature of an AII cell is its postsynaptic position to rod bipolar terminals in proximal strata of the IPL and its making gap junctions (electrical synapses) with a certain cone bipolar cell type of strata 3, 4 and 5 (Fig. $5 \mathrm{a}, \mathrm{AII}$, open arrows indicate the gap junction with the CONE BP).

The whole of Fig. 6 is devoted to showing electron micrographs of synapses to and from the dopaminergic amacrine cell in cat retina. ${ }^{62}$ The preembedding immunostain recognises Toh (a synthesising enzyme for dopamine) within the cell and stains the cell densely black (Fig. 1a). In this study we have also been able to use a second antibody stain on the first Toh-stained series of sections, thereby 

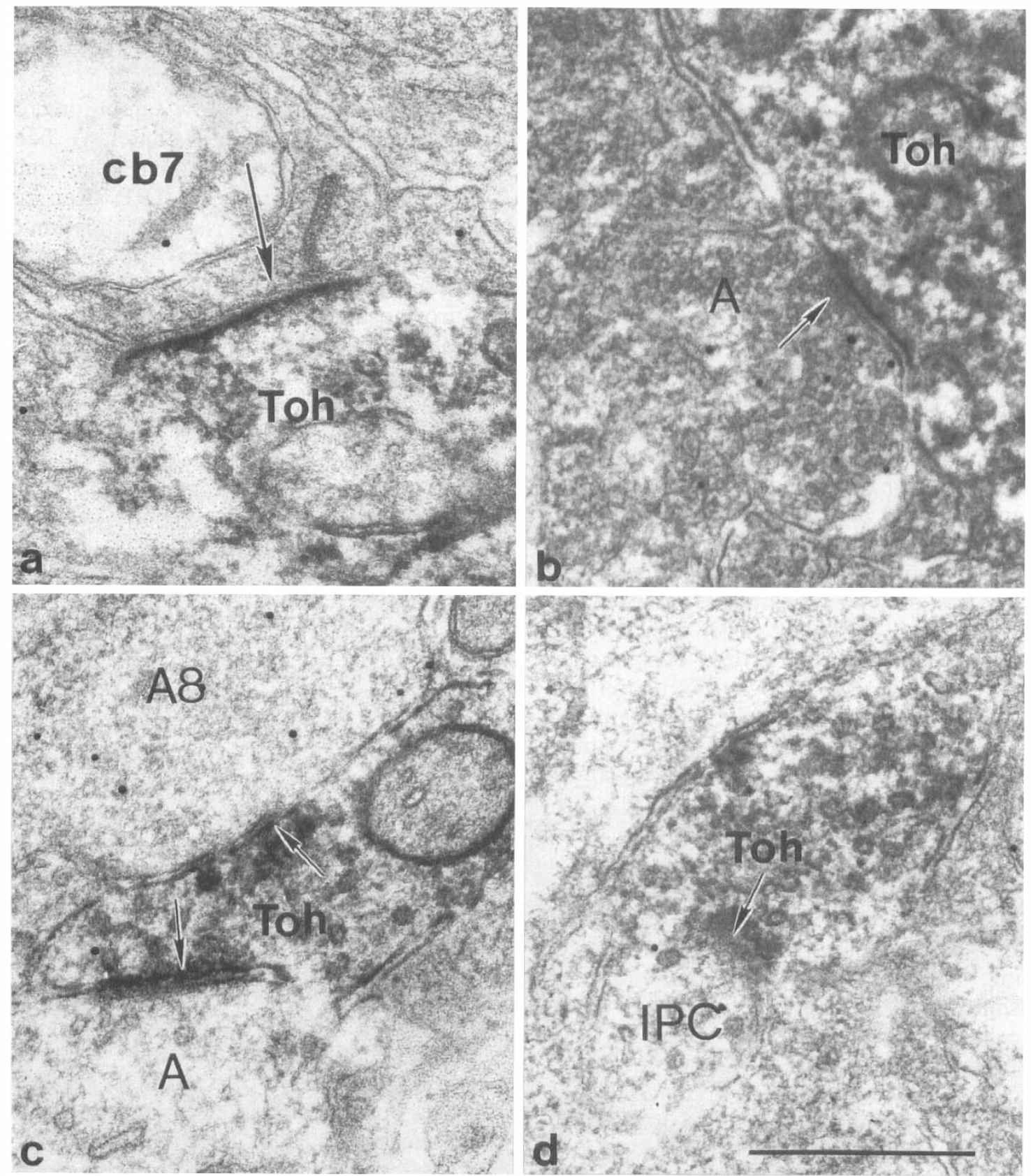

Fig. 6. Electron micrographs of synaptic relationships of the dopamine cell in cat retina. The cell is pre-embedding immunostained with antibodies to Toh. Postembedding staining with antibodies to GABA and glycine has stained the synaptic profiles involved. (a) Cone bipolar (putative cb7) input occurs to Toh dendrites in stratum 1 of the IPL. (b) An amacrine profile labelled for GABA is presynaptic to the Toh-stained cell body. (c) Toh processes are presynaptic to glycine containing A8 cell bodies. (d) The axon-like processes of Toh cells in the OPL are presynaptic to GABAergic interplexiform cell processes (IPC). Scale bar represents $0.5 \mu \mathrm{m}$.

revealing the inhibitory transmitters GABA and glycine in amacrine cells associated with the Toh cell. ${ }^{62}$ Large primary dendrites receive input from a cone bipolar type that has its axon stratified in stratum 1 (putatively a cb7 type, Fig. 6a) and from amacrine cells that immunostain for GABA (Fig. 6b, $A$, arrow, profile contains black immunogold stain for GABA) and glycine (not shown). The Tohimmunoreactive cell (Toh-IR) is presynaptic at its finer dendrites to cell bodies and primary dendrites of AII amacrine cells (not shown) and to the narrowfield bistratified A8 cells too (Fig. 6c, arrow, A8, black grains indicate immunogold staining for glycine in A8). Axon-like processes are emitted from the dendritic trees of dopaminergic amacrine cells and these are clearly immunostained in our material. One such axon-like process is seen running in the OPL and making a synaptic contact upon an interplexiform cell (Fig. 6d, arrow, IPC, black grains indicate staining in the IPC for GABA). As can be seen a 
great deal of information concerning the synaptic relationships of these amacrine cells can be gathered from such microscopy.

The A8 cell has been studied in equal detail to the Toh-IR amacrine cell, although in this case it was stained with intracellular iontophoresis of HRP after physiological recording. A section through its complete cell body and bistratified dendritic tree has been reconstructed in three dimensions. ${ }^{63}$ Fig. $7 \mathrm{a}$ and b show two of the most important synapses of this cell type. It is involved in the cone pathways of the cat retina, rather than the rod pathways that the AII is committed to. It receives its primary bipolar input from a cone bipolar cell of sublaminas $a$ and $b$, stratum 4 (Fig. 7b, cb6). Like AII amacrine cells, A8 cells also engage in gap junctions with a cone bipolar type of sublamina $b$, but the bipolar is a different type and in addition to the gap junction makes the

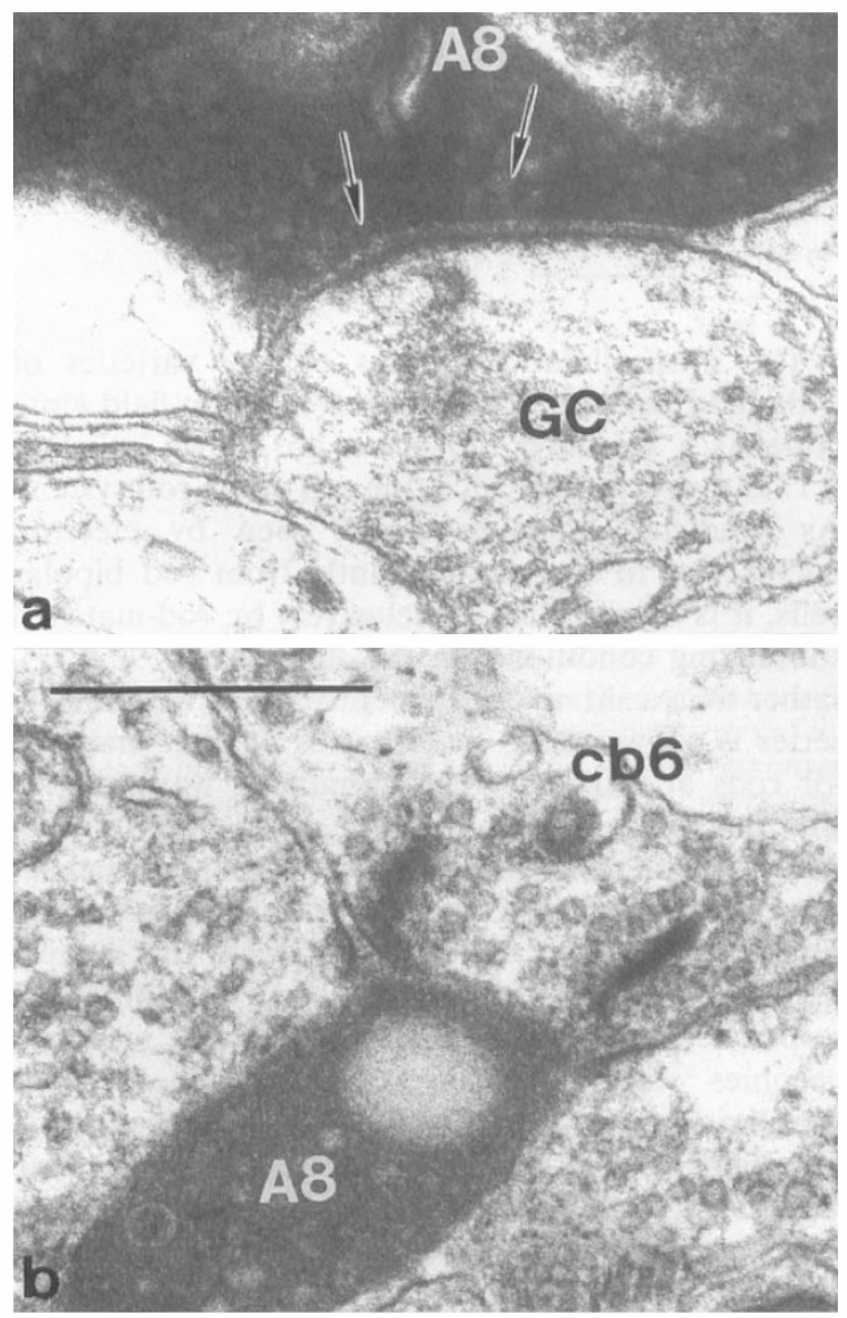

Fig. 7. Electron micrographs to show synapses of an $H R P$-injected, intracellularly recorded $A 8$ cell in cat retina. The $A 8$ dendrites in sublamina $a$ are presynaptic to $\beta$ ganglion cell dendrites $(G C)$. (b) A8 dendrites in sublamina $b$ are postsynaptic to cone bipolar (putatively cb6 type) axons. Scale bar represents $0.5 \mu \mathrm{m}$. common ribbon synapse to A8 dendrites. A8's major output is to $\mathrm{b}$ ganglion cell dendrites in sublamina a of the IPL (Fig. 7a, GC).

Golgi-stained and immunostained ACh-containing starburst amacrine cells of the rabbit retina have been extensively studied at the electron microscope level by others. ${ }^{64,65}$ Cone bipolar and amacrine cell inputs are distributed irregularly over the entire dendritic tree but the proximal dendrites containing small spines are particularly choice for bipolar input. A small amount of AII amacrine input may occur to the proximal dendrites of the ACh-a type cell. The varicosities borne on the distal ends of the dendrites (see Fig. 1b) appear to be the only sites of synaptic output to ganglion cells. The postsynaptic ganglion cells for both ACh-a and ACh-b type cells are thought to be ON-OFF directional-selective bistratified ganglion cells. ${ }^{21,22,65-69}$ Additionally, the monostratified ON-directionally selective ganglion cell may be postsynaptic to the ACh-b type cell. ${ }^{65}$

\section{INTRACELLULAR RECORDINGS FROM MAMMALIAN AMACRINE CELLS}

Making intracellular recordings of nerve cell activity in the mammalian retina has not been an easy task. All the problems associated with keeping a warmblooded species' neural retina oxygenated and perfused adequately to obtain viable signals have been and continue to be difficult to overcome. There are really only a handful of researchers capable of this task. Thus the complete information we would like to have concerning amacrine cell physiology and function coupled with morphological marking and electron microscopy of connectivity in a mammalian retina has been slow and sporadic in coming. The nine cells illustrated in Figs. 1-3 of this paper are the most completely studied to date. ${ }^{24,27,61,63,70-72}$ Fig. 8 shows sample intracellular recordings from the three narrow-field cells (A8, AII and A2), while three wide-field cells (A17, A19/22/23 and a dopaminergic amacrine (DA) cell) are shown in Fig. 9. The last cell type is not from a mammalian retina, being instead a recording from a turtle DA cell. ${ }^{73,74}$

The recordings from the cells are usually done under mesopic light conditions with a slit of light stimulating the cell in steps across its receptive field. Thus A8 at point 0 has the slit fully centred and the hyperpolarising response is at its largest magnitude. The cell is clearly an OFF-centre cell with a pronounced transient at the light off. As the slit is stepped some distance to either side of the centre of the receptive field the response of the cell inverts and a depolarising or ON-surround appears by $700 \mu \mathrm{m}$ from the central position (Fig. 8, A8, top and bottom trace).

The AII amacrine has been recorded from by several laboratories. In all species' retinas recorded 

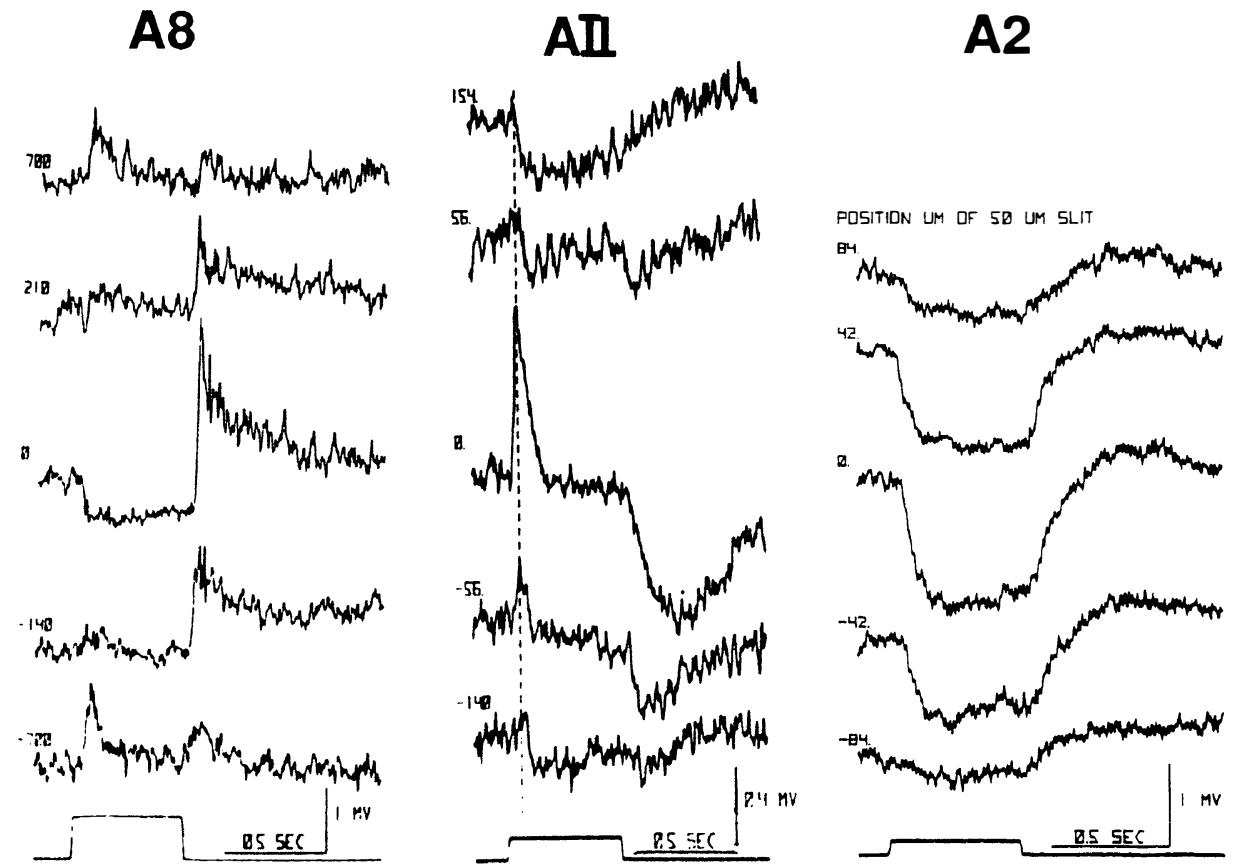

Fig. 8. Intracellular recordings from three narrow-field amacrine cells in the cat retina. Receptive fields were mapped by displacing a $50 \mu \mathrm{m}$ wide slit to either side of the cell's receptive field centre judged as the largest response. The A8 at 0 gives a sustained hyperpolarising response and a pronounced transient response at light off. Its receptive field has a depolarising surround evident by $700 \mu \mathrm{m}$ on either side of the centre. The AII cell gives a transient ON response to light on and a pronounced hyperpolarisation at light off. Its hyperpolarising surround becomes evident at 140 um to either side of centre. ${ }^{24}$ A2 is a sustained hyperpolarising amacrine cell with no surround.

from, the AII cell is a rod-dominated depolarising (ON-centre) cell. ${ }^{24,27,70}$ Thus, in the centre of its receptive field (Fig. 8, AII, 0 point) the cell gives a transient depolarising response with a pronounced sustained plateau (ON-centre) and a long drawn out hyperpolarisation after light off. By $140 \mu \mathrm{m}$ to either side of the centre, the response to a light flash is now an inverted response indicating a hyperpolarising surround (OFF-surround) ${ }^{24}$ The A2 contrasts with both $\mathrm{A} 8$ and $\mathrm{AII}$, in giving a true slow potential hyperpolarising response to light (OFF-centre) at all positions of the slit in its receptive field and having no sign of a surround (Fig. 8, A2). These three narrow-field cells have also been tested with rod and cone matched stimuli in order to determine how much of their responses is driven by cones compared with rods. The AII amacrine cell is most strongly responsive to rod or scotopic levels of light and the depolarising component of the central receptive field is similar in response characteristics to the rod bipolar cells. ${ }^{24,70}$ A8 and A13 cells, on the other hand, appear to be cone system neurons in physiological response. Wavelengths maximal for cone stimulation dominate their responses and only a small portion comes from stimulation of the rod pathways. ${ }^{63}$ Likewise A2 cells (Fig. 3) can also be shown to be primarily cone system amacrines responding with much larger slow potentials with cone matched light stimuli than with rod. ${ }^{72}$
The intracellular responses of five varieties of wide-field amacrine cell and the medium-field amacrine ACh 'starburst' amacrines are shown in Fig. 9. A17 is the reciprocal amacrine cell of the rod system. As predicted from its input, seen by electron microscopy to be predominantly from rod bipolar cells, it is driven almost exclusively by rod-matched stimulating conditions. In the figure (Fig. 9, A17), rather than a slit mapped receptive field, an intensity series is shown using wavelengths of light matched for rods at rod and cone stimulating wavelengths. The responses at each light intensity superimpose, thus indicating that only a single receptor mechanism is present - that due to the rods. At all intensities the response is a depolarisation and up to the highest intensities (bottom trace) essentially a slow potential response. At the highest light intensity the response becomes slightly transient although there is a depolarising plateau phase. The response now resembles that of its input neuron, the rod bipolar cell. ${ }^{70}$ A17 cells, however, do not appear to have inhibitory surrounds, although they do exhibit spatially dependent characteristics in their response amplitudes on stimulation with a surround. ${ }^{30}$

Amacrine cells A19, A22 and A23 are all transient depolarising ON-OFF cells. Such cells have been difficult to record long-term responses from and the example illustrated (Fig. 9, A19) is one of the longest held and thus a receptive field was mapped. A22 and 


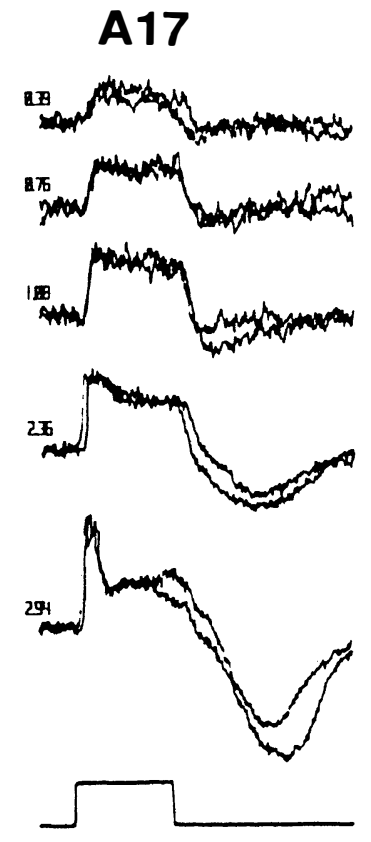

\section{turtle DA}
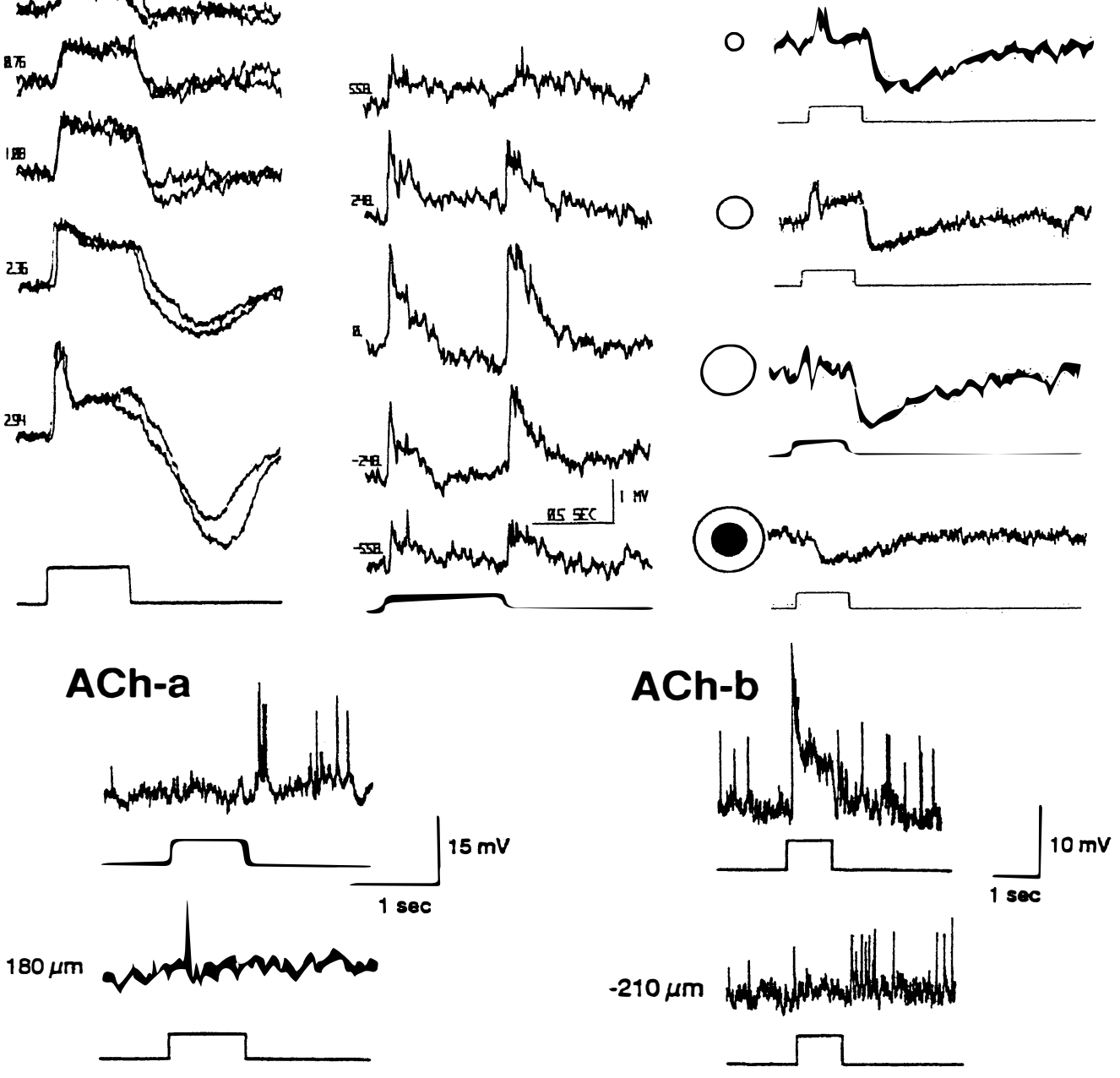

Fig. 9. Intracellular responses of five types of medium-field (ACh cells) or wide-field amacrine cells in cat and turtle retina. A17 is stimulated with a rod-matched intensity series of light of $667 \mathrm{~nm}$ and $441 \mathrm{~nm}$ respectively. The responses superimpose, indicating that the cell is purely rod-driven. The responses are sustained depolarisations to the light on (ON-centre) except at saturating stimuli (lowest trace) where a slightly more transient ON-response and a sustained plateau are seen. ${ }^{30}$ A19/22/23 all give ON-OFF responses to light. This A19 example has a wide receptive field mapped with the slits (1000 $\mu$ m diameter) and no surround mechanism. ${ }^{61}$ The turtle dopaminergic amacrine $(D A)$ gives a transient depolarisation at light on with a sustained plateau. At light off the response falls to a long drawn-out hyperpolarisation. With an annulus stimulation (bottom trace) the response is a sustained hyperpolarisation (OFF response) suggesting surround inhibition. ${ }^{74}$ The starburst-a and -b cells give transient $O F F$ and $O N$ response respectively to stimulation of their receptive field centres. Each exhibits a surround of opposite polarity: ON surround for ACh-a and OFF-surround for ACh-b type cells. Both ACh cell types have receptive field centre sizes about equal to their dendritic tree sizes. ${ }^{27}$

A23 have very similar receptive fields in being large, i.e. $>550 \mu \mathrm{m}$ radius, rather larger than their dendritic tree sizes. The large receptive fields of these cells may be due to the axon-like extensions of their central dendritic trees. ${ }^{61}$ None of the three wide-field cell types had antagonistic surrounds.

The DA cell from the turtle retina is shown here $\mathrm{e}^{73,74}$ because we do not have an unequivocal intracellular recording from an A18 cell in the mammalian retina. We suspect that the A18 cell will behave similarly to the DA cell of turtle though.
The cell gives a slight $\mathrm{ON}$ transient which continues as a sustained depolarisation during the light on. At light off, it has a very distinct slow sustained hyperpolarisation that lasts for several seconds. The increasing spot sizes bring out the depolarising $\mathrm{ON}$ plateau while with an annulus (Fig. 9, DA cell bottom trace), a sustained OFF-surround is evident. $^{73,74}$

Both mirror-symmetric pairs of starburst cells of the rabbit retina have been intracellularly recorded from and dye-marked by Bloomfield ${ }^{27}$ (Fig. 9). The 
a-type of the pair (stratifying in sublamina a) is an OFF-centre cell giving a transient burst of small spikes at light off (Fig. 9, ACh-a, top trace). When the receptive field is mapped with the slit stimulation protocol, in the same way Nelson does it, the ACh-a cell gives a small burst of spikes at light on at $180 \mu \mathrm{m}$ from the central position (Fig. 9, ACh-a, lowest trace). This indicates a surround mechanism. In a similar way, the ACh-b type of starburst cell (stratifying in sublamina b) is an ON-centre cell in the centre of the receptive field (ACh-b, top trace) but gives a burst of spikes at light off when the slit of light is stimulating the antagonistic surround region (ACh-b, bottom trace).

Reconsidering Figs. 8 and 9, it becomes obvious that there is no general principle of physiological response that can be attributed to dendritic tree structure or membrane area of these amacrine cells. For example, narrow-field cells can be transient or phasic in their physiology (A8 and AII), perhaps even with spike-producing mechanisms, just as well as sustained in response (A2). In the same vein, wide-field cells can give sustained responses (A17, turtle DA cell) or transient (A19/22/23). Of the two bistratified cells one variety is an OFF-centre cell (A8) while the other is an ON-centre cell (AII), so both ON or OFF responses can be generated by bistratified cells. Furthermore, it is not necessarily true that amacrines stratifying in sublamina a will be only OFF-centre while amacrines branching in sublamina $b$ will be only ON-centre, although the two starburst subtypes do follow this rule. The DA cell of turtle, like the dopamine amacrine of cat, the A18 cell, is primarily stratified in stratum 1 of sublamina a and is apparently an ON-centre cell: as is suspected this cell type will be in cat, because dopamine is known to be released by flickering light on (for a review see $\mathrm{Kramer}^{75}$ and Witkovsky and Dearry $\left.^{76}\right)$.

\section{SUMMARIES OF THE PRESENTLY KNOWN AMACRINE CELL CIRCUITS}

We are now able to construct wiring diagrams of nine different amacrine cell types in the mammalian retina. These are amacrine cells that can be confidently classified by their morphology and can be assigned a role in the rod or cone pathways through the retina from their physiological response characteristics. Figs. 10, 11 and 12 thus summarise the findings on the amacrine cells we have discussed in this paper.

\section{AII: A Bistratified Rod Amacrine Cell}

The narrow-field bistratified rod amacrine cell, AII, is primarily postsynaptic to rod bipolar axon terminals in lower sublamina $b$ of the IPL $(30 \%$ of its input $^{79}$ ) (Fig. 10, upper) and is known to be an ON- centre neuron driven by its ON-centre rod bipolar input. Its major output is upon ganglion cells that have dendrites only in sublamina a, i.e. AII cell lobular appendages synapse upon OFF-centre $\alpha$ and $\beta$ ganglion cells. ${ }^{60}$ The AII also passes rod-driven information through the $\mathrm{ON}$-centre cb5 cone bipolar to $\mathrm{ON}$-centre $\alpha$ and $\beta$ ganglion cells by means of gap junctions (Fig. 10, upper; black spots on AII primary dendrites to pink cb axon). A little OFF-centre cone bipolar input is provided to the AII lobular appendages by cb1 and cb2 OFF-centre cone bipolar cells in sublamina a $\left(19 \%\right.$ of input $\left.^{79}\right)$ (Fig. 10, yellow cb profiles). Thus, AII cells do carry some cone pathway components to their ON-centre responses, which could come from excitatory input from $\mathrm{ON}$-centre cb5 at the gap junctions, or from the direct $c b 1$ or $c b 2$ synapses which would have to be inhibitory, in this case. All amacrine cells are also coupled across the retina in a weak electrical syncytium by virtue of the gap junctions between their arboreal dendrites in sublamina b (Fig. 10, upper; gj, lower right). ${ }^{8,24,77}$

The dopaminergic amacrine cell provides a considerable number of synapses to the AII cell, either directly upon its cell body or upon its lobular appendages (Fig. 10, upper; A, red arrowheads ${ }^{62,78}$ ). As much as $51 \%$ of the input to AII amacrine cells is from various other amacrine cells and most of them occur in the central part of the cells' dendritic tree in strata $3-4 .^{79}$ What percentage of all these different amacrine cell inputs is from the dopaminergic amacrine cell is presently unknown. AII amacrine cells are glycine-immunoreactive. ${ }^{33,80}$ The AII amacrine cells are the major carriers of rod signals to the ganglion cells in the retina. As such they may play a role in speeding up the slow potential rod messages for presentation to ganglion cells. In addition, because of their high density across all parts of the retina and their synaptic involvement with millions of rod bipolar cells, they may contribute in a major way to the pattern ERG. ${ }^{2}$

\section{A8: A Bistratified Cone Amacrine Cell}

The narrow-field bistratified amacrine cell of the cone system, A8, receives most of its bipolar input from OFF-centre cone bipolar axons of both sublamina $\mathrm{a}$ and $\mathrm{b}$ of the IPL. ${ }^{63}$ Thus, in sublamina a, excitatory cone-driven signals come from cone bipolar cells like cb2 which we know are OFF-centre in physiology (Fig. 10, lower; yellow cb profile), and in sublamina $b$ from cb6, another OFF-centre bipolar cell (Fig. 10, lower; pink cb profile) ${ }^{81}$ Altogether cone bipolar synapses account for $42 \%$ of the input to A8 cells. Lesser rod bipolar input $(20 \%)$ also occurs to the lower dendrites in sublamina $b$ of the IPL. As A8 is an OFF-centre physiological type, ${ }^{63}$ the small ON-centre rod bipolar cell input is either 

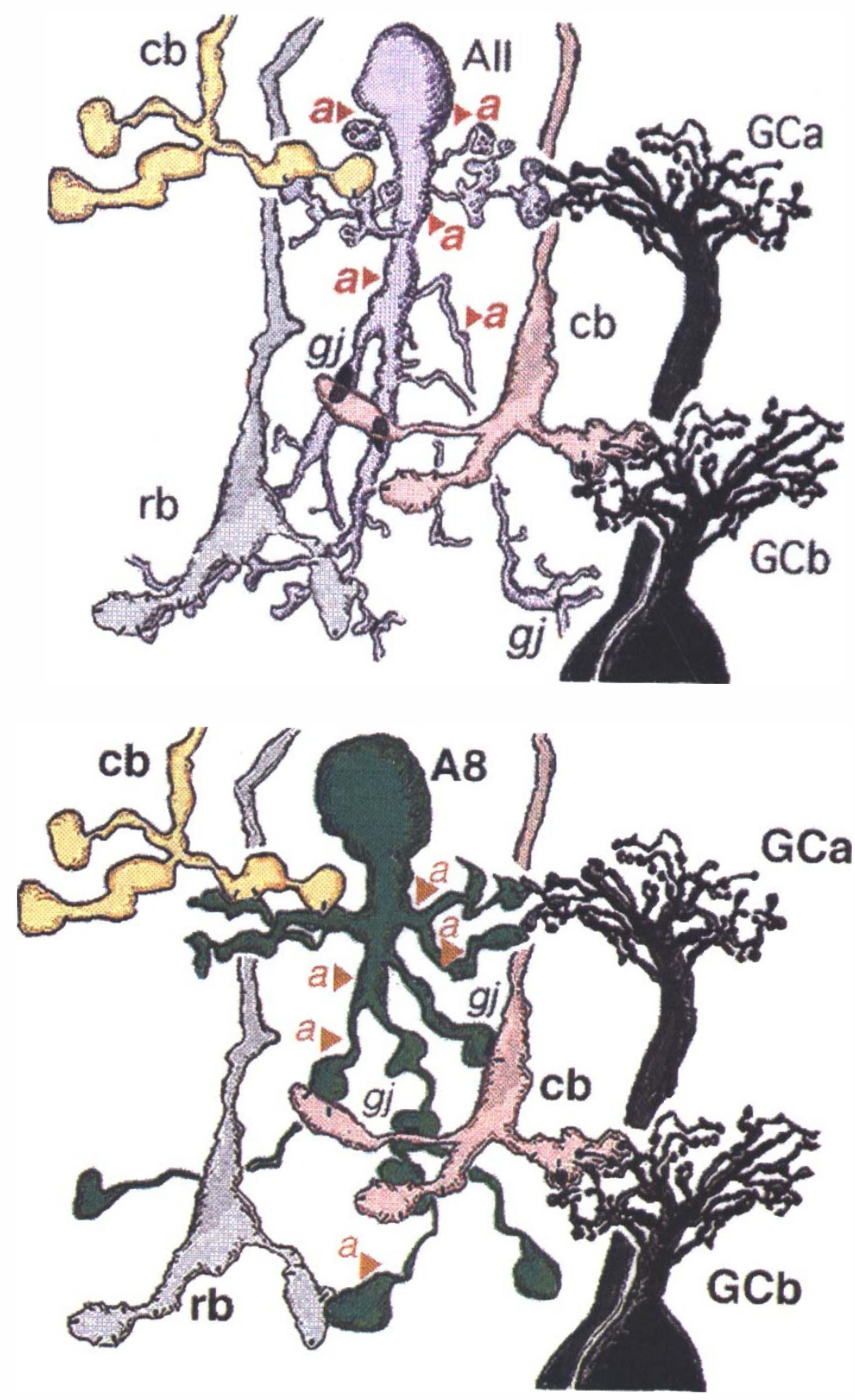

Fig. 10. Summary drawings of the neurocircuitry of the narrow-field bistratified rod AII and cone A8 cells of the mammalian retina. See text for detailed descriptions.

masked or the input is through sign-inverting synapses at the synaptic ribbons of the rod bipolar. The A8 gives a rather transient OFF-response (Fig. 8 ) which could reflect the amacrine synapses (38\% of input) occurring over all parts of its dendritic tree (Fig. 10, lower; A, red arrowheads).

The A8 amacrine cell has output to OFF-centre $\beta$ ganglion cells with dendrites in sublamina a, upon other amacrine cells and through gap junctions upon OFF-centre cb6 cone bipolar cells. ${ }^{63}$ Some part of the amacrine input to A8, particularly that upon its cell body and proximal dendrites in stratum 1 of the IPL, is from dopaminergic amacrine cells (A18). ${ }^{62}$ A 8 is intensely glycine-immunoreactive. ${ }^{62,80}$ If A8 cells are as numerous as AII cells throughout the retina, their phasic response form may very well be 
recordable in the photopic pattern ERG and oscillatory potentials.

\section{A19 and A23: ON-OFF Wide-Field Amacrine Cells}

A19 and A23 are both ON-OFF amacrine cells (Fig. 9). A19 stratifies in stratum 2 of sublamina a and A23 on the sublamina $\mathrm{a} / \mathrm{b}$ border. Both of them extend long $(500 \mu \mathrm{m})$, thin $(<0.2 \mu \mathrm{m}$ diameter $)$, beaded, axon-like processes from the tips of the major dendrites which probably extend their receptive fields.

A23 receives input from a few cb2 bipolar cells, and a few AII amacrine cell lobular appendages in sublamina a of the IPL. However, the majority of the input is from pale-appearing amacrine cells some of which could be OFF-centre A2 cells (Fig. 11, A23). The preponderance of amacrine inputs probably accounts for its transient physiology. A23's major output is to OFF-centre ganglion cell dendrites in sublamina a of the IPL, and in this respect may explain some of the latter type of ganglion cell's nonlinear response characteristics. ${ }^{82}$ A23 appears to be immunoreactive for GABA. ${ }^{61}$

A19 receives two types of cone bipolar input: the first is from OFF-centre cb2 cone bipolar cells of sublamina a, while the other is ON-centre input from $\mathrm{cb} 5$ at the sublamina $\mathrm{a} / \mathrm{b}$ border where $\mathrm{cb} 5$ passes into sublamina b. OFF- and ON-centre bipolar input
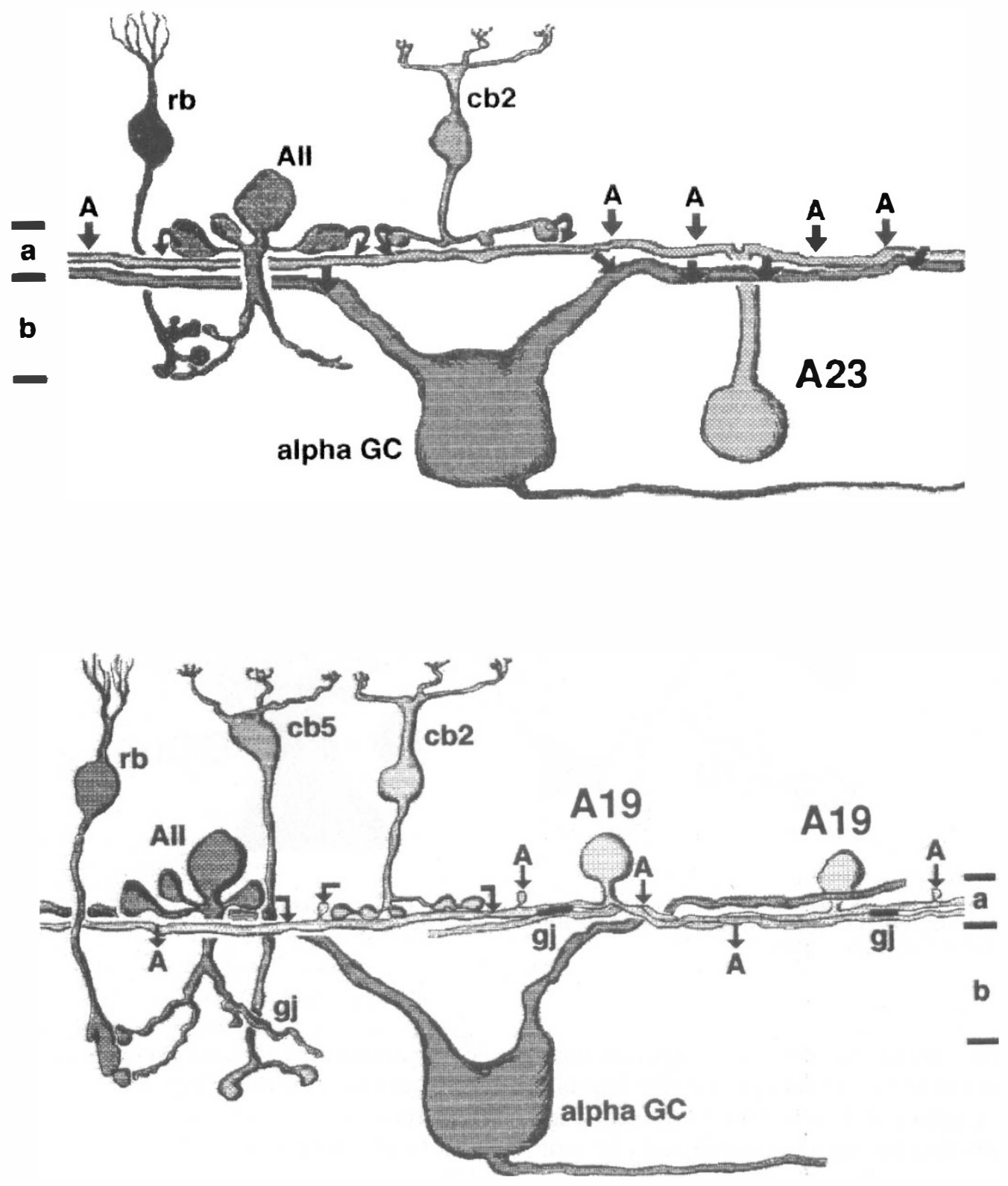

Fig. 11. Summary drawings of the neurocircuitry of wide-field ON-OFF amacrine cells A23 and A19. ${ }^{61}$ See text for detailed descriptions. 
could account for this cell's ON-OFF physiology. The predominant input is from amacrine cells of sublamina a though. Some of the amacrine inputs could be from OFF-centre A2 cells while others are probably from other A19 cells. Its output is reciprocal synapses to both types of bipolar, to unknown dark amacrines and possibly also to unknown ganglion cell profiles (Fig. 11, A19). Gap junctions may connect A19 dendrites one to another (Fig, 11, A19, gj). A19 is GABA-ergic. ${ }^{48}$ Both A19 and A23 cells are probably involved in the transfer of fast messages from one area of retina to another. They may be the basis of the proximal negative response recordable in the intraretinal ERG and in the shift effect in $\mathrm{Y}$ type ganglion cells.

\section{A2: Narrow-Field Cone Amacrine Cell of Sublamina a}

The narrow-field amacrine cell A2 branches only in sublamina a of the IPL and interconnects cone bipolar axon terminals and dendrites of OFF-centre $\mathrm{a}$ and $\mathrm{b}$ ganglion cells (Fig. 12A). In some other reports it was erroneously named $\mathrm{A} 4 ;^{71,72}$ however, its branching in strata 1 and 2 of sublamina a, rather than in strata 2 and 3, as does the otherwise similarappearing A4, causes us to rename this cell type as an A2. A2 cells receive bipolar input from OFFcentre $\mathrm{cb} 1$ and $\mathrm{cb} 2$ types of cone bipolar cell and make reciprocal synapses to the bipolar axons. The OFF-centre A2 amacrine cell response is then fed to OFF-centre ganglion cell dendrites. If the A2 cell makes inhibitory synapses upon ganglion cells, as is likely because it is thought to be a GABA-ergic cell type,${ }^{48}$ it might function in a disinhibitory role to the centre response. Alternatively, A2 cells, despite being small-field types, might have a role in the generation of antagonistic surrounds of ganglion cells. ${ }^{60} \mathrm{~A} 2$ cells receive a great many amacrine inputs to their dendritic trees which could be from wider field cells than they are themselves.
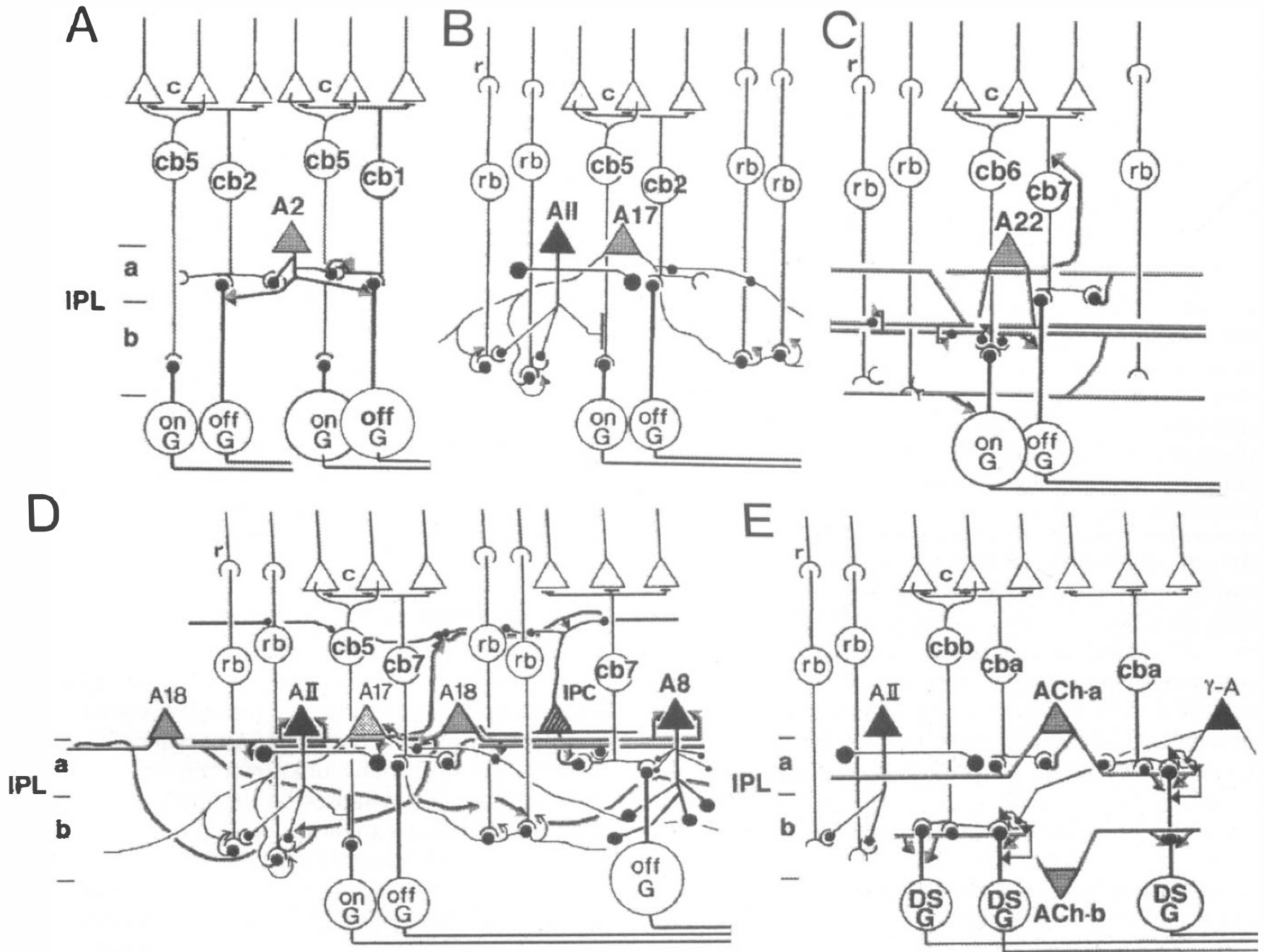

Fig. 12. Summary diagrams of $(A)$ the narrow-field $A 2$ cone amacrine; $(B)$ the wide-field $A 17$ rod amacrine cell; $(C)$ the wide-field ON-OFF amacrine A22, thought to be SP-containing; (D) the wide-field dopaminergic amacrine cell, A18; (E) the two mirror-symmetric 'starburst' ACh-a and ACh-b types. See text for detailed descriptions. 


\section{A17: The Wide-Field Reciprocal Rod Amacrine Cell}

A17 is an ON-centre rod pathway neuron that has a relatively simple wiring diagram (Fig. 12B). Its huge coverage of the IPL neuropil by its up to $1 \mathrm{~mm}$ dendritic spread, allows it to collect scotopic rod signals from several thousand rod bipolar axons. A17 is most commonly the other member of the dyad at which the AII amacrine cell receives rod bipolar input. Like the AII its ON-centre response reflects the rod-generated ON-centre message. ${ }^{70}$ But unlike the AII, the A17 cell's only output is presently thought to be purely reciprocal synapses to the rod bipolar from which it receives input (Fig. 12B) ${ }^{30}$ It is exquisitely light sensitive and may play a role in converging rod signals from huge areas of retina and amplifying them at very low light intensities. Like the AII and A8 cells, A17 cell bodies and dendrites, as they pass through stratum 1 of the IPL, are synapsed upon by the dopaminergic amacrine cell processes (not shown in Fig. 12B but see Fig. 12D). Several other 'pale' and 'dark' appearing amacrine cell inputs also occur upon the A17 cell's dendrites in sublamina a of the IPL. ${ }^{30} \mathrm{~A} 17$ is known to accumulate serotonin in rabbit retina ${ }^{21}$ but is thought to be a GABA-ergic neuron in terms of neurotransmission, in all mammalian retinas. ${ }^{48}$

\section{A22: A Putative Substance P Containing, ON-OFF Neuron of the Cone System}

A22 cells of cat retina are ON-OFF wide-field amacrine cells, often having cell bodies displaced to the ganglion cell layer, with their major dendritic stratification in strata 3 and 4 of the IPL. However, they have long axon-like processes that pass up into sublamina a. A22 cells show close morphological similarity to substance-P-immunoreactive (SP-IR) amacrine cells in the human retina and so we are proposing that they are equivalent cells. SP-IR amacrines are wide-field cells with large cell bodies $(16 \mu \mathrm{m}$ diameter) lying in normal or displaced positions on either side of the IPL. Their sturdy, spiny dendrites stratify predominantly in stratum 3 of the IPL and are postsynaptic with reciprocal synapses to putative OFF-centre cone bipolar cb6 cells (Fig. 12C). They also receive synapses from unidentified amacrine cells and other SP-IR cell dendrites. A22 cells are presynaptic to ganglion cell dendrites and directly to ganglion cell bodies (possibly some of the latter are of SP-IR ganglion cells). Axon-like processes pass from the dendritic plexus in stratum 3 to run in stratum 1 or stratum 5 and even down to the nerve fibre layer or up to the OPL. These axonal processes are presynaptic to amacrine and ganglion cells in stratum 5 and in stratum 1 to OFF-centre ganglion cells. They receive cone bipolar input from a putative cb7 type in stratum 1 of the IPL, and where their axon-like processes ascend to the OPL, they are also presynaptic to cone bipolar cells of unknown type (Fig. $12 \mathrm{C}$, shown for neatness to be presynaptic to $\mathrm{cb} 7$, but this is not proved yet). They are also concerned with innervating blood vessels in the nerve fibre layer (not shown). Almost certainly A22 cells, SP-IR amacrine cells of cat and human are GABA-ergic. ${ }^{83}$ This ONOFF cell probably plays a similar role to the A19 and A23 cells in being recordable in the PNR and being involved in fast temporal aspects of the visual coding of the ganglion cells.

\section{A18: The Dopaminergic Amacrine Cell}

This wide-field amacrine cell (A18), that is an ONcentre cell in the turtle retina, makes most of its synaptic arrangements in stratum 1 of the IPL (Fig. 12D). Sparse cone bipolar input, putatively from cb7, occurs to the cell's primary dendrites in stratum 1 . Both the cell body and primary dendrites in stratum 1 of the IPL also receive GABA-ergic and glycinergic amacrine cell inputs. The major output of the A18 cell is in the fine network of dendrites around the cell bodies and apical dendrites of OFF-centre A8 and ON-centre AII cells (Fig. 12D). It is possible that glycinergic A4 amacrine cells ${ }^{80}$ also receive a few synapses from the Toh + dendrites.

Cell bodies and fine dendrites in stratum 1 of $\mathrm{ON}$ centre A17 amacrine cells are also postsynaptic to dopamine cells. ${ }^{30}$ Furthermore, GABA-ergic profiles, belonging to the interplexiform cell of cat retina, are postsynaptic to the dopamine cell axonlike processes that run in the OPL (Fig. 12D, IPC) ${ }^{62}$ while AII amacrine arboreal dendrites in sublamina $\mathrm{b}$, close to their synapses with rod bipolar cells, are also postsynaptic to dopamine cell axon-like processes (Fig. 12D). Dopaminergic amacrine cells are thought to function in the circadian cycle of the shift from dark to light conditions, and in modulating the adaptational state of the whole retina.

\section{ACh Amacrines: Mirror Symmetric Starburst Cells}

OFF-centre ACh-a cells receive synaptic input to their proximal dendrites from a cone bipolar cell of sublamina a (presumably an OFF-centre cone bipolar), from ON-centre AII amacrine cell lobular appendages and many unknown amacrine cells. At the ACh-a cell's synapses to the upper tier of ONOFF, bistratified ganglion cells, often a reciprocal, putatively GABA-ergic amacrine cell is involved in a local circuit (Fig. 12E, $\gamma$-A). The GABA amacrine is postsynaptic to a cone bipolar input, with a reciprocal synapse, and presynaptic to the ganglion cell dendrite in the vicinity of the ACh-a cell's synapses upon the ganglion cell. ${ }^{65}$ The mirror-symmetric, ONcentre ACh-b cell makes similar synapses with the 
lower tier of dendrites of the bistratified ON-OFF directionally selective (DS) ganglion cell (Fig. 12E, DS G, right). In this case the bipolar cell involved in the direct synapses and in the GABA-ergic amacrine local circuit is presumably an $\mathrm{ON}$-centre cone bipolar cell. It is possible that the monostratified ON DS ganglion cell is also driven by ACh-b input (Fig. 12, DS G, left). ${ }^{65} \mathrm{ACh}$ amacrine cells are thus thought to be involved in the generation of DS in certain retinal ganglion cells, particularly in rabbits and turtles with visual streak topography. They may not be as well developed in foveal-based retinas such as cat and human.

The work has been supported over the years by grants EY04855 and EY03323 from the NIH and from an unrestricted grant from Research to Prevent Blindness Corp. to the Department of Ophthalmology.

Key words: Morphology, Electron microscopy, Intracellular recording, Wiring diagrams.

\section{REFERENCES}

1. Heckenlively JR, Arden GB. Principles and practice of clinical electrophysiology of vision. St Louis: MosbyYear Book.

2. Zrenner E. The physiological basis of the pattern electroretinogram. Prog Ret Res 1990;9:427-64.

3. Cajal SR. The structure of the retina (transl by SA Thorpe and M Glickstein). Springfield, Ill: CC Thomas, 1972.

4. Dogiel A. Die retina der Ganoiden. Arch Mikrosk Anat 1883;22:419-72.

5. Boycott BB, Dowling JE. Organization of the primate retina: light microscopy. Phil Trans R Soc Lond B 1969; 255:109-84

6. Famiglietti EV. 'Starburst' amacrine cells and cholinergic neurons: mirror-symmetric ON and OFF amacrine cells of rabbit retina. Brain Res 1983;261:138-44.

7. Famiglietti EV. Polyaxonal amacrine cells of rabbit retina: morphology and stratification of PA1 cells. J Comp Neurol 1992;316:391-405.

8. Famiglietti EV, Kolb H. A bistratified amacrine cell and synaptic circuitry in the inner plexiform layer of the retina. Brain Res 1975;84:293-300.

9. Kolb H. The morphology of the bipolar cells, amacrine cells and ganglion cells in the retina of the turtle Pseudemys scripta elegans. Phil Trans R Soc Lond B 1982;298:355-93.

10. Kolb H, Linberg KA, Fisher SK. The neurons of the human retina: a Golgi study. J Comp Neurol 1992; 318:147-87.

11. Kolb H, Nelson R, Mariani A. Amacrine cells, bipolar cells and ganglion cells of the cat retina: a Golgi study. Vision Res 1981;21:1081-114.

12. Kolb H, Perlman I, Normann RA. Neural organization of the turtle Mauremys caspica. Vis Neurosci 1988; $1: 47-72$.

13. Mariani AP. Amacrine cells of the rhesus monkey retina. J Comp Neurol 1990;301:382-400.

14. Polyak SL. The retina. Chicago: University of Chicago, 1941.

15. Rodieck RW. The primate retina. Comp Primate Biol (Neurosci) 1988;4:203-78.
16. Rodieck RW. Starburst amacrine cells of the primate retina. J Comp Neurol 1989;285:18-37.

17. Wagner H-J, Wagner E. Amacrine cells in the retina of a teleost fish, the roach (Rutilus rutilus): a Golgi study. Phil Trans R Soc Lond B 1988;321:263-324.

18. West RW. Light and electron microscopy of the ground squirrel retina: functional considerations. J Comp Neurol 1976;168:355-78.

19. Famiglietti EV, Kolb H. Structural basis for ON- and OFF-center responses in retinal ganglion cells. Science 1976;194:193-5.

20. Nelson R, Famiglietti EV, Kolb H. Intracellular staining reveals different levels of stratification for on-center and off-center ganglion cells in the cat retina. J Neurophysiol 1978;41:427-83.

21. Vaney DI. The mosaic of amacrine cells in the mammalian retina. Prog Ret Res 1990;9:49-100.

22. Tauchi M, Masland RH. The shape and arrangement of the cholinergic neurons in the rabbit retina. Proc $\mathrm{R}$ Soc Lond B 1984;223:101-19.

23. Vaney DI. 'Coronate' amacrine cells in the rabbit retina have the 'starburst' morphology. Proc $\mathrm{R}$ Soc Lond B 1984;224:475-88.

24. Nelson R. AII amacrine cells quicken the time course of rod signals in the cat retina. J Neurophysiol 1982; 47:928-47.

25. Kolb H, Famiglietti EV. Rod and cone pathways in the inner plexiform layer of the cat retina. 1974;186:47-9.

26. Vaney DI, Gynther IC, Young HM. Rod-signal interneurons in the rabbit retina: II. AII amacrine cells. J Comp Neurol 1991;310:154-69.

27. Bloomfield SA. Relationship between receptive and dendritic field size of amacrine cells in the rabbit retina. J Neurophysiol 1992;68:711-25.

28. Dacey DM. The dopaminergic amacrine cell. J Comp Neurol 1990;301:461-89.

29. Kolb H, Cuenca N, Wang H-H, DeKorver L. The synaptic organization of the dopaminergic amacrine cell in the cat retina. J Neurocytol 1990;19:343-66.

30. Nelson R, Kolb H. A17: a broad-field amacrine cell of the rod system in the retina of the cat. J Neurophysiol 1985;54:592-614.

31. Marc RE. The anatomy of multiple GABAergic and glycinergic pathways in the inner plexiform layer of the goldfish retina. In: Weiler $\mathrm{R}$, Osborne $\mathrm{E}$, editors. Neurobiology of the inner retina. Berlin: Springer, 1989:53-64.

32. Marc RE. Visualizing amino acids in the retina. Great Basin Visual Science Symposium, University of Utah. 1994:58-68.

33. Crooks J, Kolb H. Localization of GABA, glycine, glutamate and tyrosine hydroxylase in the human retina. J Comp Neurol 1992;315:287-302.

34. Brecha N, Johnson D, Peichl L, Wassle H. Cholinergic amacrine cells of the rabbit retina contain glutamate decarboxylase and $\gamma$-aminobutyrate immunoreactivity. Proc Natl Acad Sci USA. 1988;85:6187-91.

35. Chun M-H, Wässle $\mathrm{H}$, Brecha N. Colocalization of $\left[{ }^{3} \mathrm{H}\right]$ muscimol uptake and choline acetyltransferase immunoreactivity in amacrine cells of the cat retina. Neurosci Lett 1988;94:259-63.

36. Kosaka T, Tauchi M, Dahl JL. Cholinergic neurons contain GABA-like and glutamic acid decarboxylaselike immunoreactivity in various brain regions of the rat. Exp Brain Res 1988;70:605-17.

37. O'Malley DM, Masland RH. Co-release of acetylcholine and GABA by a retinal neuron. Invest Ophthalmol Vis Sci (Suppl) 1988;29:273. 
38. Agardh E, Ehinger B. Retinal GABA neuron labeling with $\left[{ }^{3} \mathrm{H}\right]$ isoguvacine in different species. Exp Eye Res 1983;36:215-29.

39. Vaney DI, Young HM. GABA-like immunoreactivity in cholinergic amacrine cells of the rabbit retina. Brain Res 1988;438:369-73.

40. Sagar SM. Somatostatin-like immunoreactive material in the rabbit retina: immunohistochemical staining using monoclonal antibodies. J Comp Neurol 1987; 266:291-9.

41. Sagar SM, Marshall PE. Somatostatin-like immunoreactive material in associational ganglion cells of human retina. Neuroscience 1988;27:507-16.

42. Brecha NC, Oyster CW, Takahashi ES. Identification and characterization of tyrosine hydroxylase immunoreactive amacrine cells. Invest Ophthalmol Vis Sci 1984;25:66-70.

43. Nguyen-Legros J. Morphology and distribution of catecholamine-neurons in mammalian retina. Prog Ret Res 1988;7:113-47.

44. Kidd M. Electron microscopy of the inner plexiform layer of the retina in the cat and the pigeon. $J$ Anat 1962;96:179-87.

45. Dowling JE, Boycott BB. Organization of the primate retina; electron microscopy. Proc $\mathrm{R}$ Soc Lond $\mathrm{B}$ 1966;166:80-111.

46. Kolb H. The inner plexiform layer in the retina of the cat: electron microscopic observations. J Neurocytol 1979;8:295-329.

47. Masland RH. Amacrine cells. Trends Neurosci 1988; 11:405-10.

48. Pourcho RG, Goebel DJ. Neuronal subpopulations in cat retina which accumulate the GABA agonist $\left[{ }^{3} \mathrm{H}\right]$ muscimol: a combined Golgi and autoradiographic study. J Comp Neurol 1983;219:25-35.

49. Sandell JH, Masland RH, Raviola E, Dacheux RF. Connections of indoleamine-accumulating cells in the rabbit retina. J Comp Neurol 1989;283:303-13.

50. Allen RA. The retinal bipolar cells and their synapses in the inner plexiform layer. In: Straatsma BR, Hall MO, Allen RA, Crescitelli F. Berkeley and Los Angeles: University of California Press, 1969:101-43.

51. Kolb H. Organization of the outer plexiform layer of the primate retina: electron microscopy of Golgiimpregnated cells. Phil Trans $\mathrm{R}$ Soc Lond $\mathrm{B}$ 1970;258:261-83.

52. Kolb H, DeKorver L. Midget ganglion cells of the parafovea of the human retina: a study by electron microscopy and serial section reconstructions. J Comp Neurol 1991;303:617-36.

53. McGuire BA, Stevens JK, Sterling P. Microcircuitry of bipolar cells in cat retina. J Neurosci 1984;4:2920-38.

54. McGuire BA, Stevens JK, Sterling P. Microcircuitry of beta ganglion cells in cat retina. J Neurosci 1986; 6:907-18.

55. Sterling P. Microcircuitry of the cat retina. Annu Rev Neurosci 1983;6:149-85.

56. Stevens JK, McGuire BA, Sterling P. Toward a functional architecture of the retina: serial reconstruction of adjacent ganglion cells. Science 1980;207:317-9.

57. Eldred WD, Zucker C, Karten HJ, Yazulla S. Comparison of fixation and penetration enhancement techniques for use in ultrastructural immunocytochemistry. J Histochem Cytochem 1983;31:285-92.

58. Lasansky A. Contacts between receptors and electrophysiologically identified neurones in the retina of the larval tiger salamander. J Physiol (Lond) 1978; 285:531-42.
59. Cuenca N, DeKorver L, Kolb H, DeJuan J. Neurocircuitry of substance $P$ containing amacrine cells in the human retina. Invest Ophthalmol Vis Sci (Suppl) 1994;35:1492.

60. Kolb H, Nelson R. Off-alpha and off-beta ganglion cells in the cat retina. II. Neural circuitry as revealed by electron microscopy of HRP stains. J Comp Neurol 1993;329:85-110.

61. Freed MA, Pflug R, Kolb H, Nelson R. ON-OFF amacrine cells in cat retina. J Comp Neurol 1996; 364:556-66.

62. Kolb H, Cuenca N, DeKorver L. Postembedding immunocytochemistry for GABA and glycine reveals the synaptic relationships of the dopaminergic amacrine cell of the cat retina. J Comp Neurol 1991; 310:267-84.

63. Kolb H, Nelson R. Hyperpolarizing, small-field amacrine cells in cone pathways of cat retina. J Comp Neurol 1996;371:415-36.

64. Brandon C. Cholinergic neurons in the rabbit retina: dendritic branching and ultrastructural connectivity. Brain Res 1987;426:119-30.

65. Famiglietti EV. Synaptic organization of starburst amacrine cells in rabbit retina: analysis of serial thin sections by electron microscopy and graphic reconstruction. J Comp Neurol 1991;309:40-70.

66. Amthor FR, Oyster CW, Takahashi ES. Morphology of on-off direction-selective ganglion cells in the rabbit retina. Brain Res 1984;298:187-90.

67. Amthor FR, Takahashi ES, Oyster CW. Morphologies of rabbit retinal ganglion cells with complex receptive fields. J Comp Neurol 1989;280:97-121.

68. Famiglietti EV. Starburst amacrine cells in cat retina are associated with bistratified, presumed directionally selective, ganglion cells. Brain Res 1987;413:404-8.

69. Vaney DI. Territorial organization of direction-selective ganglion cells in rabbit retina. J Neurosci 1994;14:6301-16.

70. Dacheux RF, Raviola E. The rod pathway in the rabbit: a depolarizing bipolar and amacrine cell. J Neurosci 1986;6:331-45.

71. Kolb H, Nelson R. Neural architecture of the cat retina. Prog Ret Res 1984;3:21-60.

72. Kolb H, Nelson R. Functional neurocircuitry of amacrine cells in the cat retina. In: Gallego A, Gouras $P$, editors. Neurocircuitry of the retina: a Cajal memorial. New York: Elsevier, 1985:215-32.

73. Ammermuller J, Kolb H. The organization of the turtle inner retina. I. The organization of on- and off-center pathways. J Comp Neurol 1995;358:1-34.

74. Kolb H, Netzer E, Ammermüller J. Neural circuitry and light responses of the clopamine amacrine cell of the turtle retina. Molecular Vision 1997;3,6. http:// www.emory.edu/molvis/v3/kolb.

75. Kramer SG. Dopamine: a retinal neurotransmitter. I. Retinal uptake, storage, and light stimulated release of $\left[{ }^{3} \mathrm{H}\right]$ dopamine in vivo. Invest Ophthalmol 1971; 10:438-52.

76. Witkovsky P, Dearry A. Functional roles of dopamine in the vertebrate retina. Prog Ret Res 1991;11:247-92.

77. Vaney DI. Patterns of neuronal coupling in the retina. Prog Ret Res 1994;13:301-89.

78. Voigt $\mathrm{T}$, Wassle $\mathrm{H}$. Dopaminergic innervation of AII amacrine cells in mammalian retina. $J$ Neurosci 1987;7:4115-28.

79. Strettoi E, Raviola E, Dacheux RF. Synaptic connections of the narrow-field, bistratified rod amacrine cell (AII) in the rabbit retina. J Comp Neurol 1992; 325:152-68. 
80. Pourcho RG, Goebel DJ. A combined Golgi and autoradiographic study of $\left[{ }^{3} \mathrm{H}\right]$ glycine-accumulating amacrine cells in the cat retina. J Comp Neurol 1985;233:473-80.

81. Nelson R, Kolb H. Synaptic patterns and response properties of bipolar and ganglion cells in the cat retina. Vision Res 1983;23:1183-95.
82. Enroth-Cugell C, Robson J. The contrast sensitivity of retinal ganglion cells of the cat. J Physiol (Lond) 1966;187:517-52.

83. Pourcho RG, Goebel DJ. Colocalization of substance $P$ and GABA in amacrine cells of the cat retina. Brain Res 1988;447:164-8. 